Prepared in cooperation with the Tennessee Department of Environment and Conservation, Division of Water Resources

\title{
Public-Supply Water Use and Self-Supplied Industrial Water Use in Tennessee, 2010
}

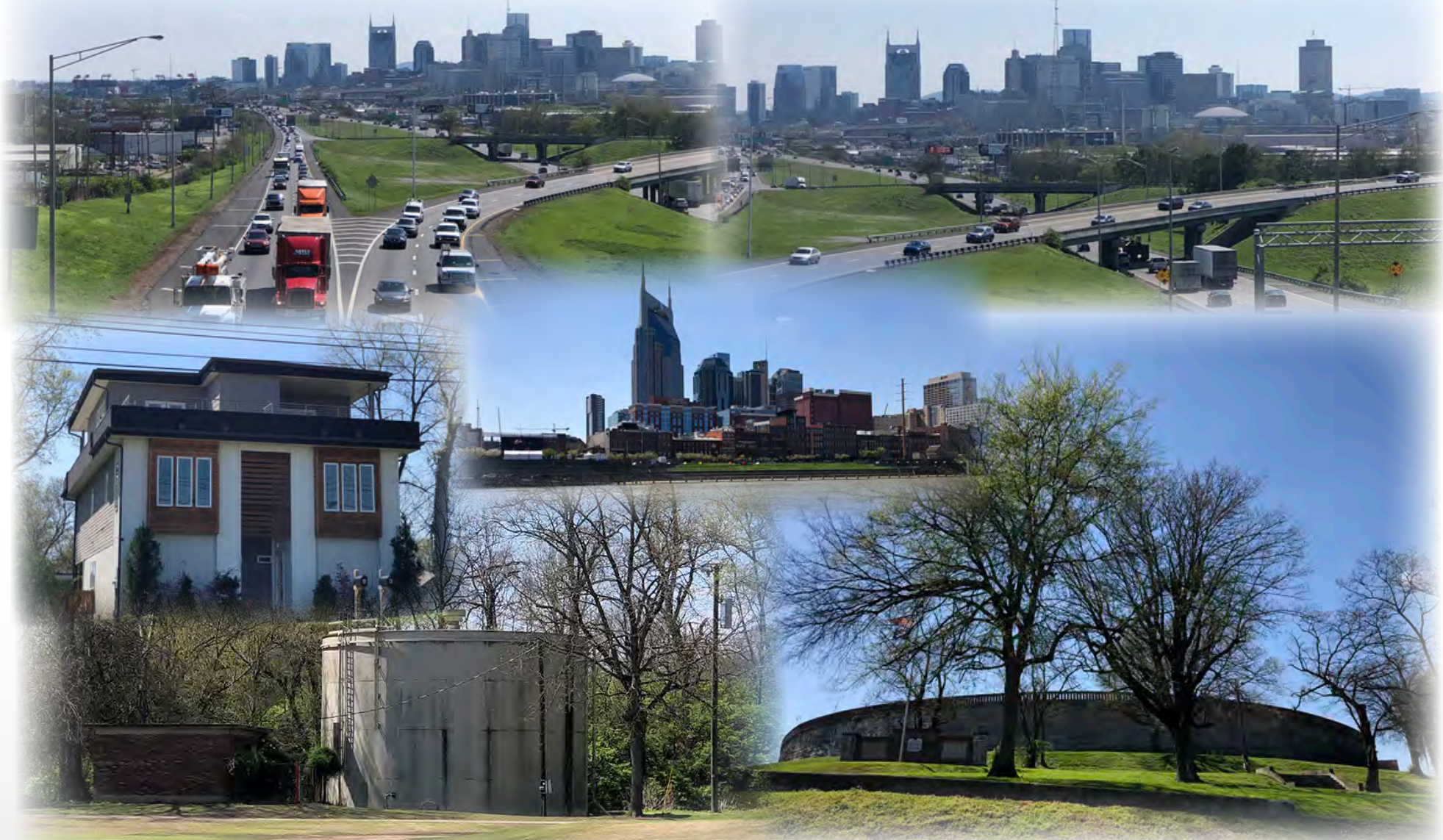

Scientific Investigations Report 2018-5009 
Cover photographs, left column, top to bottom: Skyline of Nashville, Tennessee; view north of Nashville. Urban residence, north Nashville, Tennessee. Water reservoir along Richland Creek, a tributary to the Cumberland River, Nashville, Tennessee.

Cover photographs, right column, top to bottom: Skyline of Nashville, Tennessee; view north of Nashville. Historic Eighth Avenue South Reservoir in Nashville, Tennessee. The elliptical reservoir was built in the late 1880 s as a settling basin. This reservoir was designated as an American Water Landmark by the American Water Works Association in 1971 and a Metro Nashville Landmark in 2004.

Cover photograph, center: View of downtown Nashville, Tennessee, from the east bank of the Cumberland River.

All photographs by John A. Robinson, U.S. Geological Survey. 


\section{Public-Supply Water Use and Self-Supplied Industrial Water Use in Tennessee, 2010}

By John A. Robinson

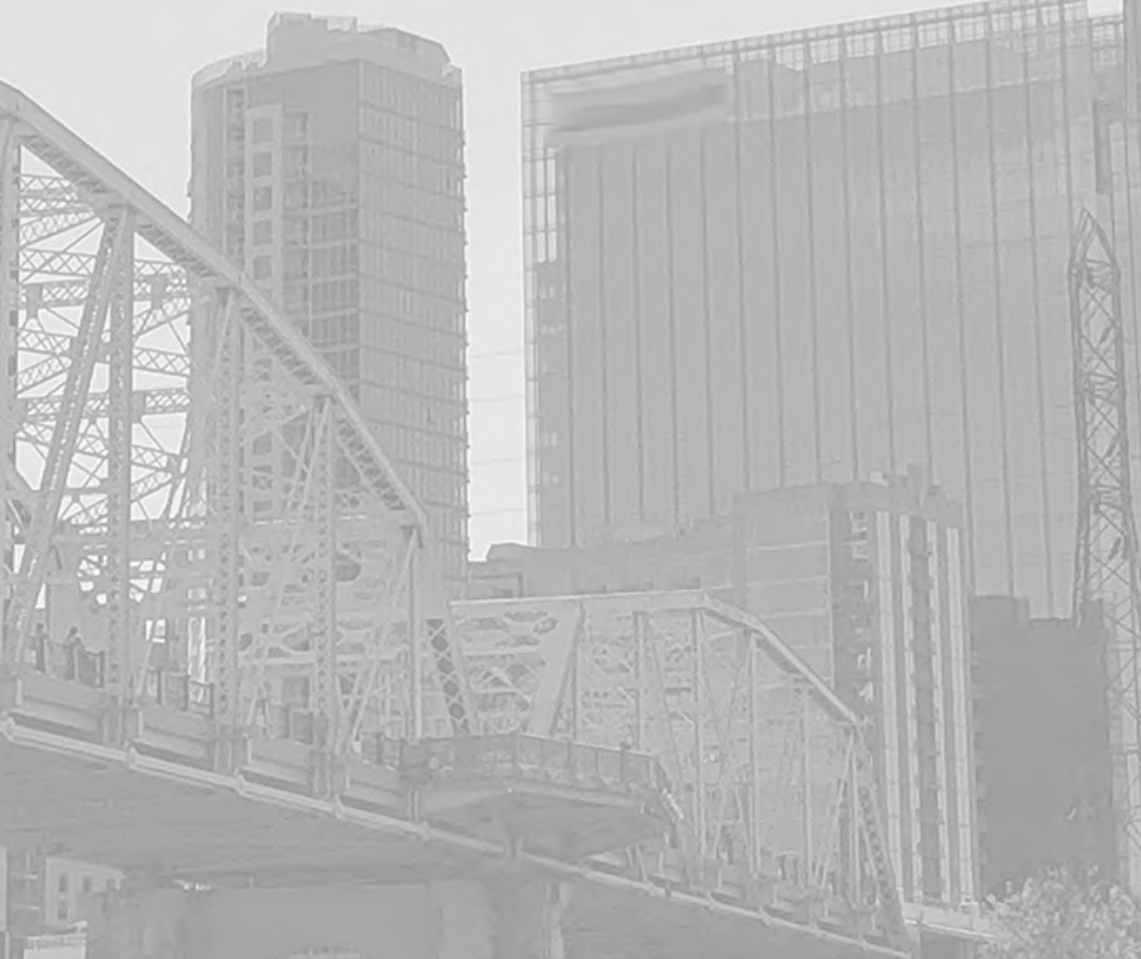

Prepared in cooperation with the Tennessee Department of Environment and Conservation, Division of Water Resources

Scientific Investigations Report 2018-5009 


\title{
U.S. Department of the Interior \\ RYAN K. ZINKE, Secretary
}

\section{U.S. Geological Survey William H. Werkheiser, Deputy Director exercising the authority of the Director}

\author{
U.S. Geological Survey, Reston, Virginia: 2018
}

For more information on the USGS - the Federal source for science about the Earth, its natural and living resources, natural hazards, and the environment-visit https://www.usgs.gov or call 1-888-ASK-USGS.

For an overview of USGS information products, including maps, imagery, and publications, visit https://store.usgs.gov.

Any use of trade, firm, or product names is for descriptive purposes only and does not imply endorsement by the U.S. Government.

Although this information product, for the most part, is in the public domain, it also may contain copyrighted materials as noted in the text. Permission to reproduce copyrighted items must be secured from the copyright owner.

Suggested citation:

Robinson, J.A., 2018, Public-supply water use and self-supplied industrial water use in Tennessee, 2010:

U.S. Geological Survey Scientific Investigation Report 2018-5009, 30 p., https://doi.org/10.3133/sir20185009.

ISSN 2328-0328 (online) 


\section{Contents}

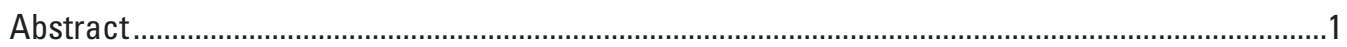

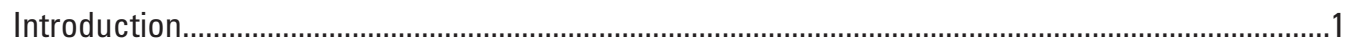

Purpose and Scope ...........................................................................................................

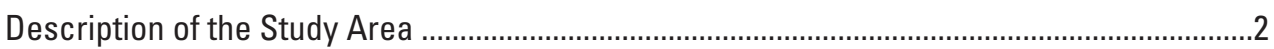

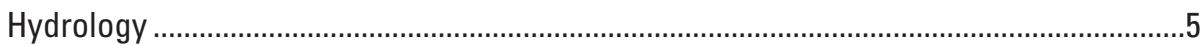

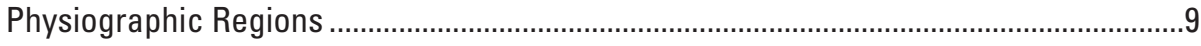

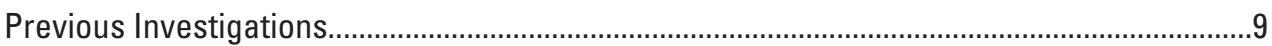

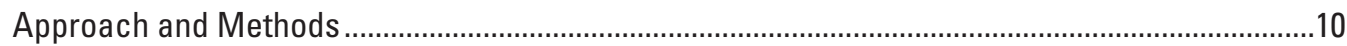

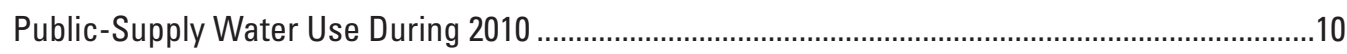

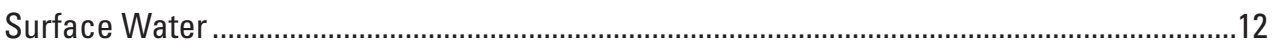

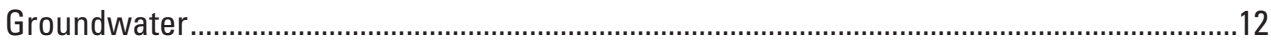

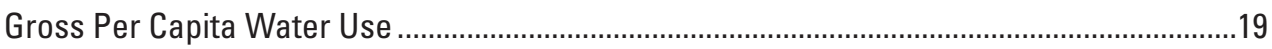

Self-Supplied Industrial Water Use During 2010 ……................................................................19

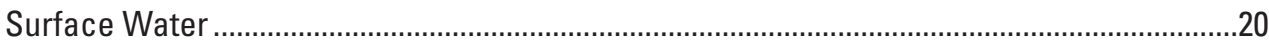

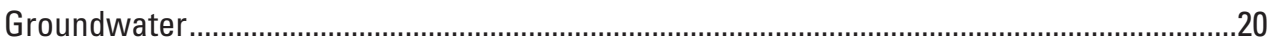

Summary

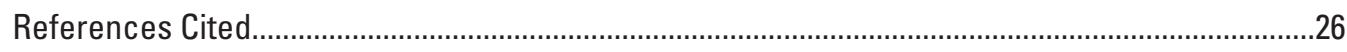

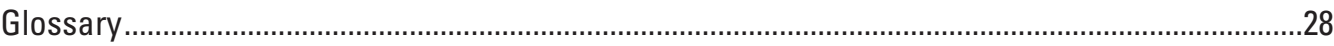

Appendix 1. Public-Supply Water Systems and Associated Water Use in the Tennessee Hydrologic Region, 2010.......................................................................................29

Appendix 2. Public-Supply Water Systems and Associated Water Use in the Ohio Hydrologic

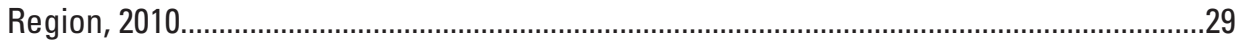

Appendix 3. Public-Supply Water Systems and Associated Water Use in the LowerMississippi Hydrologic Region, 2010.............................................................................29

Appendix 4. Self-Supplied Industrial Water Use in the Tennessee Hydrologic Region, 2010.........29

Appendix 5. Self-Supplied Industrial Water Use in the Ohio Hydrologic Region, 2010...................29

Appendix 6. Self-Supplied Industrial Water Use in the Lower Mississippi Hydrologic

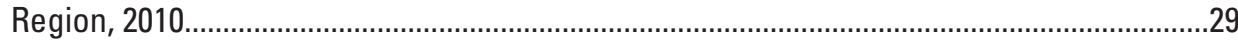

Appendix 7. Public-Supply Water Systems in Tennessee, 2010 ................................................29

\section{Figures}

1. Maps showing regions and basins in Tennessee. Modified from Webbers .....................3

2. Map showing counties and primary population centers in West, Middle, and East Tennessee $\ldots$

3. Map showing primary tributaries of the Mississippi, Tennessee, and Cumberland Rivers in Tennessee...................................................................................................

4. Maps showing principal aquifers and generalized geologic section in Tennessee .........7

5. Graph showing surface-water and groundwater withdrawals by public-supply water systems in Tennessee, 1950 to 2010.

6. Diagram showing source of water use for public-supply water systems in Tennessee in 2010 .

7. Map showing distribution of public-supply water systems using surface water or groundwater in Tennessee in 2010 
8. Map showing public-supply surface-water withdrawal rates for Tennessee counties in 2010 .

9. Map showing public-supply groundwater withdrawal rates for Tennessee counties in 2010 ..

10. Graph showing public-supply groundwater withdrawals, in million gallons per day, from principal aquifers in Tennessee in 2010.

11. Map showing principal aquifers in Tennessee and rate of public-supply groundwater withdrawals, in million gallons per day, 2010.

12. Diagram showing source of water for self-supplied industry in Tennessee in 2010 .......19

13. Map showing self-supplied industrial surface-water withdrawal rates for Tennessee counties in 2010

14. Map showing self-supplied industrial groundwater withdrawal rates for Tennessee counties in 2010

15. Graph showing self-supplied industrial groundwater withdrawals, in million gallons per day, from principal aquifers in Tennessee in 2010

16. Map showing principal aquifers in Tennessee and rate of self-supplied industrial groundwater withdrawals in million gallons per day, 2010

\section{Tables}

1. Surface-water characteristics of the hydrologic subregions and major river basins in Tennessee

2. Aquifer and well characteristics in Tennessee.

3. Surface-water withdrawals by public-supply water systems from Tennessee river basins in 2010

4. Groundwater withdrawals by public-supply water systems in Tennessee using 1 million gallons per day or more

5. Self-supplied industrial withdrawals by category and source in Tennessee in $2010 \ldots . .19$

6. Self-supplied industrial surface-water withdrawals from Tennessee river basins in 2010 . 


\section{Conversion Factors}

U.S. customary units to International System of Units

\begin{tabular}{|c|c|c|}
\hline Multiply & By & To obtain \\
\hline \multicolumn{3}{|c|}{ Length } \\
\hline inch (in.) & 2.54 & centimeter (cm) \\
\hline \multicolumn{3}{|c|}{ Area } \\
\hline square mile $\left(\mathrm{mi}^{2}\right)$ & 2.590 & square kilometers $\left(\mathrm{km}^{2}\right)$ \\
\hline \multicolumn{3}{|c|}{ Volume } \\
\hline gallons (gal) & 3.785 & liter (L) \\
\hline gallons (gal) & 0.003785 & cubic meter $\left(\mathrm{m}^{3}\right)$ \\
\hline acre-foot (acre-ft) & 1,233 & cubic meter $\left(\mathrm{m}^{3}\right)$ \\
\hline \multicolumn{3}{|c|}{ Flow rate } \\
\hline gallons per minute (gal/min) & 0.06309 & liters per second (L/s) \\
\hline gallons per day (gal/d) & 0.003785 & cubic meters per day (m³/d) \\
\hline million gallons per day (Mgal/d) & 0.04381 & cubic meters per second $\left(\mathrm{m}^{3} / \mathrm{s}\right)$ \\
\hline
\end{tabular}

\section{Selected Water Equivalents in U.S. Customary Units}

1 gallon (gal) $=8.34$ pounds $(\mathrm{lb})$

1 million gallons (Mgal)=3.07 acre-feet (acre-ft)

1 cubic foot $\left(\mathrm{ft}^{3}\right)=62.4$ pounds (lb) or 7.48 gallons (gal)

1 acre-foot (acre-ft)=325,851 gallons (gal) or 43,560 cubic feet $\left(\mathrm{ft}^{3}\right)$

1 inch of rain (in.)=17.4 million gallons per square mile (Mgal/m2), 27,200 gallons per acre (gal/acre), or 100 tons per acre (ton/acre)

\section{Datum}

Vertical coordinate information is referenced to the National Geodetic Vertical Datum of 1929 (NGVD 29).

Horizontal coordinate information is referenced to the North America Datum of 1983 (NAD 83).

\section{Altitude}

Altitude, as used in this report, refers to the distance above the vertical datum. 


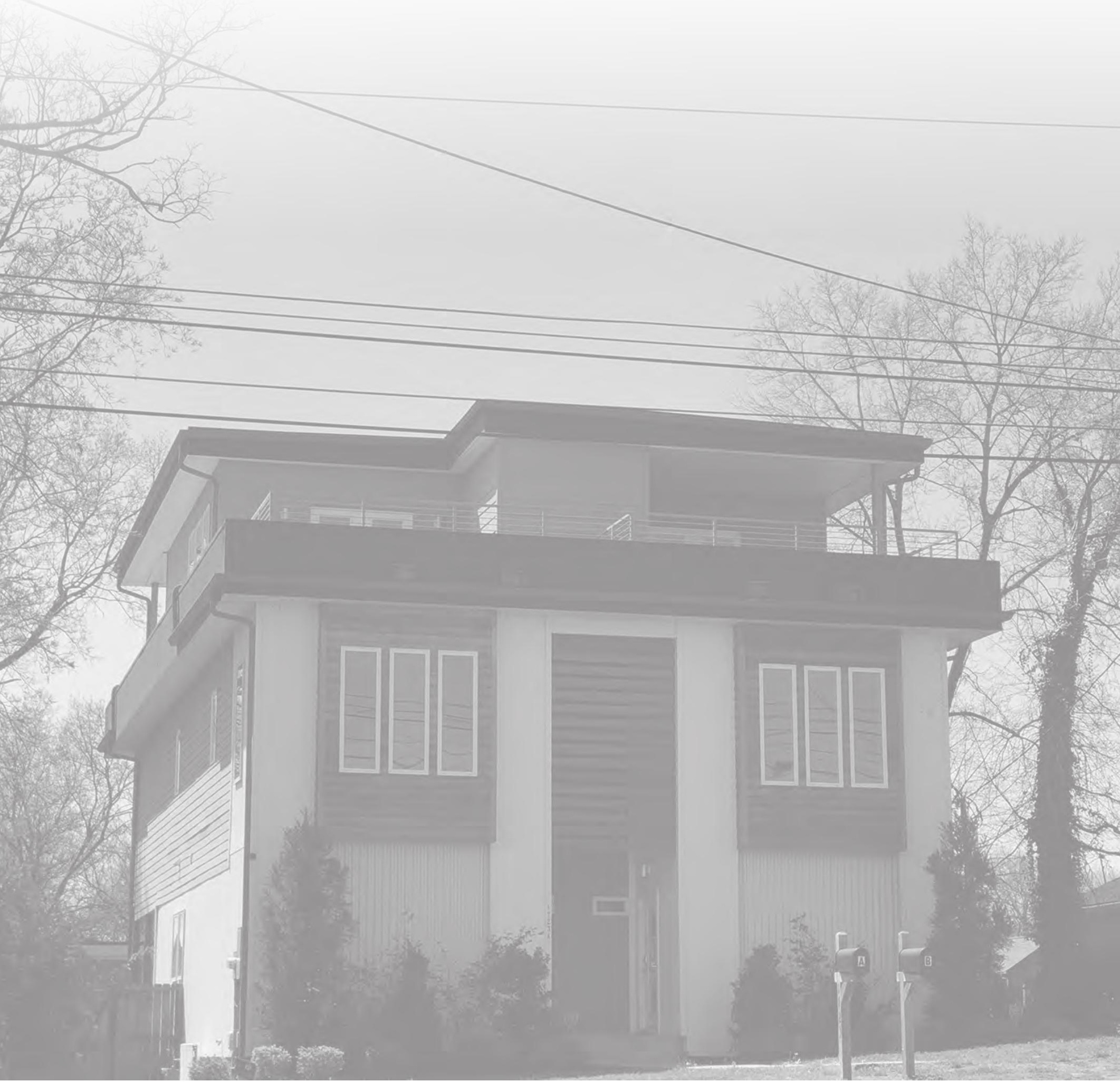




\title{
Public-Supply Water Use and Self-Supplied Industrial Water Use in Tennessee, 2010
}

\author{
By John A. Robinson
}

\section{Abstract}

The U.S. Geological Survey (USGS), in cooperation with the Tennessee Department of Environment and Conservation, Division of Water Resources, prepared this report and displayed and analyzed water use by self-supplied industrial and public-supply water systems in Tennessee for 2010. Public-supply water systems in Tennessee provide water for domestic, industrial, and commercial uses and for municipal services. In 2010, 474 public-supply water systems distributed 917 million gallons per day (Mgal/d) of surface water (67 percent, $617 \mathrm{Mgal} / \mathrm{d}$ ) and groundwater (33 percent, $300 \mathrm{Mgal} / \mathrm{d}$ ) to a population of 5.7 million in Tennessee. Gross per capita water use in Tennessee during 2010 was 162 gallons per day.

Since 1950, water withdrawals by public-supply water systems in Tennessee have increased from $160 \mathrm{Mgal} / \mathrm{d}$ to $917 \mathrm{Mgal} / \mathrm{d}$ in 2010. Each of the 95 counties in Tennessee was served by at least 1 public-supply water system in 2010. Tennessee public-supply water systems withdraw less groundwater than surface water, and surface-water use has increased at a faster rate than groundwater use. Since 2005, surface-water withdrawals have increased by $26 \mathrm{Mgal} / \mathrm{d}$, and groundwater withdrawals have decreased by $29 \mathrm{Mgal} / \mathrm{d}$, which is the first decrease in groundwater withdrawals since 1950; however, 29 systems reported increased groundwater withdrawals during 2010, and 12 of these 29 systems reported increases of $1 \mathrm{Mgal} / \mathrm{d}$ or more. Davidson County had the largest surface-water withdrawal rate (136 Mgal/d) in 2010. The largest groundwater withdrawal rate $(151 \mathrm{Mgal} / \mathrm{d})$ by a single public-supply water system was reported by Memphis Light, Gas and Water, which served more than 669,000 people in Shelby County in 2010.

Self-supplied industrial water use includes water for such purposes as fabrication, processing, washing, diluting, cooling, or transporting a product; incorporating water into a product; or for sanitation needs in facilities that manufacture various products. Water withdrawals for self-supplied industrial water use during 2010 were about $776 \mathrm{Mgal} / \mathrm{d}$. This quantity represented a decrease of $7 \mathrm{Mgal} / \mathrm{d}$ since 2005. In Tennessee, self-supplied industrial water withdrawals were primarily for chemical and allied products (555 Mgal/d), paper and allied products (107 Mgal/d), aeronautical products (71.5 Mgal/d), concrete and glass products $(9.74 \mathrm{Mgal} / \mathrm{d})$, and primary metal products (4.49 Mgal/d); and these products accounted for 96 percent $(747 \mathrm{Mgal} / \mathrm{d})$ of the self-supplied industrial water withdrawals in 2010. Surface water supplied 94 percent of the water (728 Mgal/d) for self-supplied industrial purposes, and groundwater supplied 6 percent (47.6 Mgal/d). Selfsupplied industrial water withdrawals in Sullivan County were $488 \mathrm{Mgal} / \mathrm{d}$ and accounted for 61 percent of the self-supplied industrial water withdrawals. The largest groundwater withdrawal, $14.9 \mathrm{Mgal} / \mathrm{d}$, by a single self-supplied industry was in Memphis, Tennessee, for the production of chemicals and allied products.

\section{Introduction}

The water resources in Tennessee are likely to be stressed in the future by factors such as population increase, urban and suburban development, climate change, and other competing demands. As these stressors increase, water-resource managers and policymakers will need timely and accurate information regarding water use as part of effective regional water-supply planning for infrastructure investment, conservation, and cost-recovery strategies. Quantifying public-supply water use and self-supplied industrial water-use information, and understanding the effects of water use on water resources and natural hydrologic systems, is important for the public and policymakers.

The population of Tennessee in 2010 was estimated as 6,346,105 by the U.S. Census Bureau (2012). As Tennessee's population has increased with time, so too has the number of people and industries relying on additional water resources. Public supply refers to water withdrawn by public or private suppliers that furnish water year round to at least 25 people or have at least 15 service connections (U.S. Geological Survey, 1978). Estimates of self-supplied industrial withdrawals by facilities with usage of 10,000 gallons per day (gal/d) or more were obtained from the Tennessee Department of Environment and Conservation (TDEC) or from a water-use 
inventory conducted by TDEC in conjunction with this investigation (Tennessee Department of Environment and Conservation, 2015). Studies documenting water withdrawals by self-supplied industrial and public-supply water systems provide local and regional government agencies with a better understanding of past and current water use and a basis for accurate estimation of future water needs.

\section{Purpose and Scope}

The U.S. Geological Survey (USGS), in cooperation with the TDEC Division of Water Resources (DWR), prepared this report to display a detailed analysis on water use by self-supplied industrial and public-supply water systems in Tennessee; additionally, this report presents the sources of these water uses (withdrawals) and quantities of water withdrawn.

The 2010 water-use data were obtained from the TDECDWR, which regulates self-supplied industrial and publicsupply water system withdrawals and usage within Tennessee. Public-supply water-use data before 2010 were obtained from published USGS reports. The data analyses for this report include graphic summaries and descriptions of water use in Tennessee from 1950 to 2010.

\section{Description of the Study Area}

Tennessee is in the central southeastern United States, bounded by the Mississippi River on the west and extending to the Blue Ridge physiographic region on the east (fig. 1). Tennessee encompasses 42,126 square miles ( $\left.\mathrm{mi}^{2}\right)$, which includes $926 \mathrm{mi}^{2}$ of inland water (Webbers, 2003). Landsurface altitudes range from 180 feet (ft) above the National Geodetic Vertical Datum of 1929 (NGVD 29) along the Mississippi River to more than 6,600 ft above the NGVD 29 in the Great Smoky Mountains of East Tennessee. The three grand divisions of Tennessee shown in figure 2-West Tennessee, Middle Tennessee, and East Tennessee - are characterized by distinct differences in geology, physiography, and hydrology. In West Tennessee, thick unconsolidated sedimentary aquifers provide water for public supply and self-supplied industry. In Middle and East Tennessee, publicsupply and self-supplied industrial water originates primarily from surface-water sources and, in places, from groundwater sources such as wells and springs.
The climate in Tennessee generally is temperate, warm, and humid. Precipitation in the form of short-duration thunderstorms happens from late spring through early fall. Storms from December through May can last for several days and produce large amounts of precipitation. During 2007 to 2012, parts of Tennessee have had record floods and droughts. Moderate to extreme drought happened in the spring, summer, and fall of 2007 and 2008; and in the summer of 2012 (U.S. Drought Monitor, 2007, 2008, 2012). Moderate to extreme flooding happened in the spring of 2010 (National Weather Service, 2010) and 2011 (National Oceanic and Atmospheric Administration, 2011). The record floods and droughts have affected the demands for reservoir storage and flood control (Griffin, 2006) and natural aquifer recharge in Tennessee.

The climate in Tennessee is temperate with warm summers and mild winters. In general, the temperature and precipitation in Tennessee is a function of the varying topography from West to Middle to East Tennessee. The average annual precipitation for the State of Tennessee was 53.6 inches (in.) from 1981 to 2010. The months with the most precipitation were March, April, and May with an average of 14.8 in. of precipitation per month. The months with the least precipitation were September, October, and November with an average of 11.9 in. of precipitation per month. The annual average temperature for Tennessee was 57.8 degrees Fahrenheit $\left({ }^{\circ} \mathrm{F}\right)$; temperatures were lowest in January, February, and December with an average temperature of $38.7^{\circ} \mathrm{F}$ and highest in June, July, and August with an average temperature of $75.9^{\circ} \mathrm{F}$ (National Centers for Environmental Information, 2013).

The population of Tennessee increased 11.5 percent from 2000 to 2010, and Tennessee was the 17th most populated State in the United States during 2010. According to the U.S. Census Bureau as of 2010, the primary population centers shown in figure 2 include Memphis $(646,889)$, Shelby County; Nashville (601,221), Davidson County; Knoxville $(178,874)$, Knox County; Chattanooga (167,674), Hamilton County; Clarksville (132,929), Montgomery County; and Murfreesboro (108,755), Rutherford County (U.S. Census Bureau, 2012). During 2000 to 2010, the fastest growing counties in Tennessee were Williamson, Rutherford, Fayette, Wilson, Montgomery, Sevier, Louden, Sequatchie, and Sumner Counties (Center for Business and Economic Research, 2012). 
$\boldsymbol{A}$
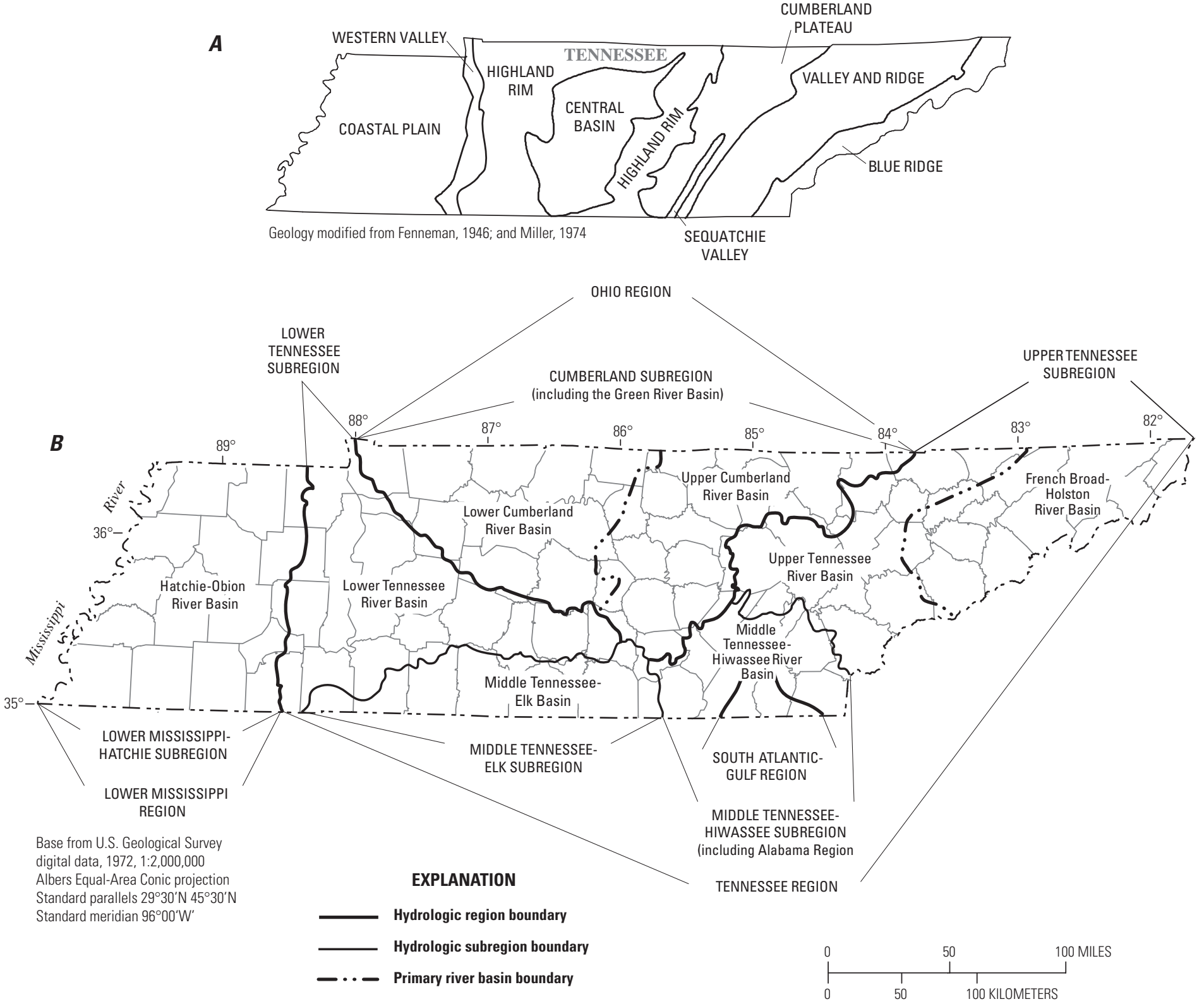

Figure 1. Regions and basins in Tennessee. Modified from Webbers (2003). $A$, physiographic regions; and, $B$, primary hydrologic regions and subregions and primary river basins. 


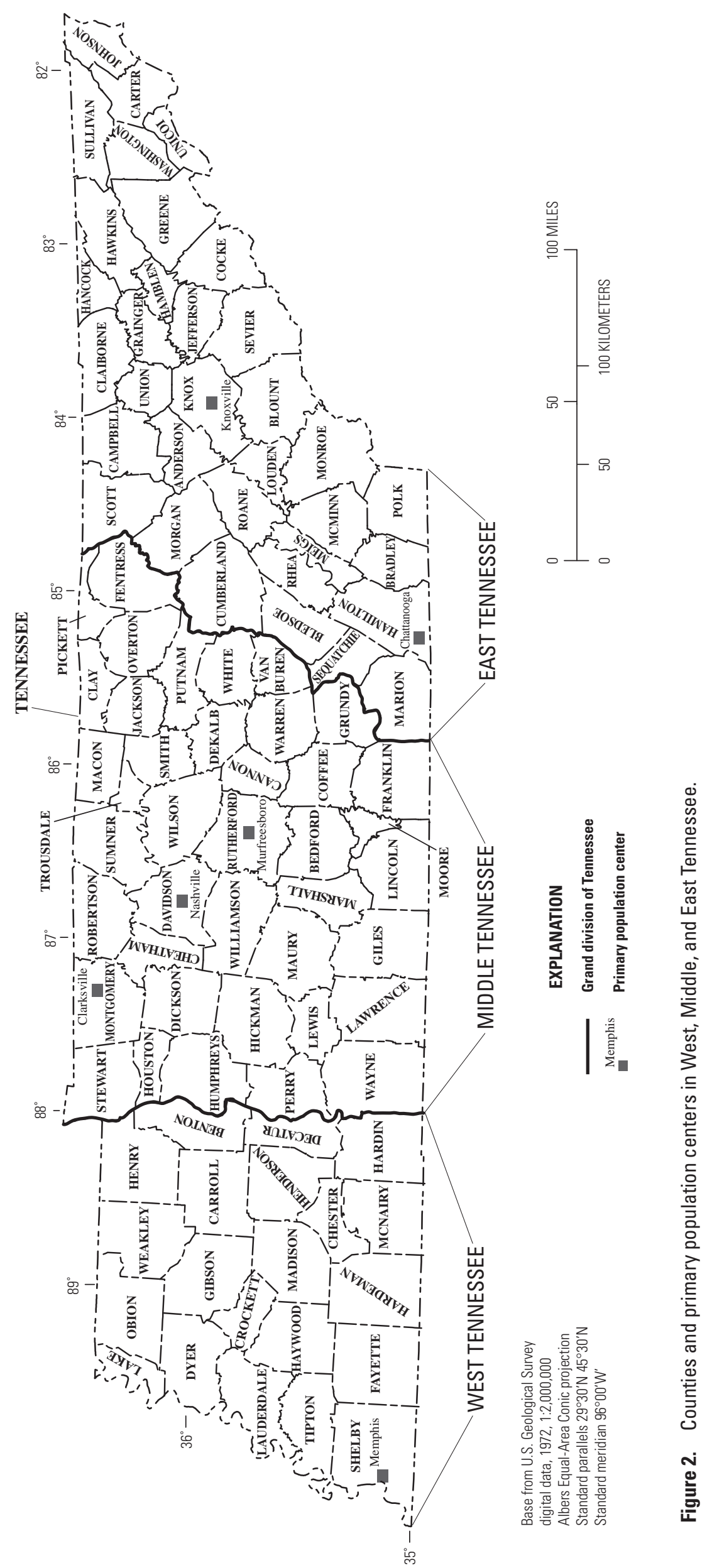




\section{Hydrology}

Information on hydrologic regions presented in this section is from Webbers (2003) unless cited otherwise. Three primary hydrologic regions divide the State's surface-water hydrography from West Tennessee to East Tennessee- the Lower Mississippi, the Ohio, and the Tennessee hydrologic regions (fig. 1). A small part of southeastern Tennessee is in the South Atlantic-Gulf hydrologic region. Within the primary hydrologic regions are six, smaller hydrologic subregions containing river basins that determine water drainage within the State (table 1).

In Middle and East Tennessee, the Ohio hydrologic region includes the Cumberland River and its tributaries. The primary tributaries of the Cumberland River shown in figure 3 are the Obey, Caney Fork, Harpeth, Stones, and Red Rivers of the Cumberland subregion. In West, Middle, and East Tennessee, the Tennessee hydrologic region includes the Tennessee River and its primary tributaries shown in figure 3, including the Buffalo, Beech, Big Sandy, and Duck Rivers of the Lower Tennessee subregion; the Elk, Shoal, and Flint Rivers of the Middle Tennessee-Elk subregion; and the Clinch, French Broad, Holston, Nolichucky, Powell, and Tellico Rivers of the Upper Tennessee subregion. The Lower and Upper Cumberland and Lower and Upper Tennessee River
Basins include an extensive network of reservoirs that store about 8.12 million acre-feet (2,647 billion gallons) of water (Hutson, 1990). In West Tennessee, the Lower MississippiHatchie hydrologic subregion drains about 8,907 mi². Surfacewater characteristics of the hydrologic subregions and primary river basins in Tennessee are described in table 1.

Groundwater for public supply in Tennessee is provided by eight of the nine principal aquifers in the State (table 2). The principal aquifers in Tennessee that are used for public supply are the alluvial (Quaternary), Tertiary sand, Cretaceous sand, Pennsylvanian sandstone, Mississippian carbonate rock, Ordovician carbonate rock, Cambrian-Ordovician carbonate rock, and crystalline rock (Precambrian and Cambrian) aquifers (Hollyday and Bradley, 1985; fig. 4). During 2010, 62 percent of the groundwater used for public supplies and self-supplied industry in Tennessee was produced from the Tertiary sand aquifers in West Tennessee. In Middle and East Tennessee, groundwater may be produced from wells or discharge at large springs, which are used for water supplies. Detailed descriptions and water-quality information for the aquifers in Tennessee are provided in the following reports: Brahana and Bradley (1985), Brahana and others (1986a, 1986b), Parks and Carmichael (1989), and Kingsbury and Parks (1993).

Table 1. Surface-water characteristics of the hydrologic subregions and major river basins in Tennessee.

[From Webbers (2003)]

\begin{tabular}{|c|c|c|c|c|}
\hline Hydrologic subregion ${ }^{1}$ & $\begin{array}{l}\text { Major river basin and } \\
\text { associated streams }\end{array}$ & $\begin{array}{c}\text { Physiographic divisions } \\
\text { (Miller, 1974) }\end{array}$ & Response to drought & Remarks \\
\hline $\begin{array}{l}\text { Lower Mississippi- } \\
\text { Hatchie }\end{array}$ & $\begin{array}{l}\text { Hatchie-Obion } \\
\text { Obion } \\
\text { Hatchie } \\
\text { Loosahatchie } \\
\text { Wolf } \\
\text { Nonconnah } \\
\text { Forked Deer }\end{array}$ & Coastal Plain & $\begin{array}{l}\text { Sustained flow from } \\
\text { groundwater in main } \\
\text { stem during dry } \\
\text { months. Small streams } \\
\text { will be dry. }\end{array}$ & $\begin{array}{l}\text { Few available storage } \\
\text { sites. High sediment } \\
\text { load and poor water } \\
\text { quality limits use; } \\
\text { pumps must use filters. }\end{array}$ \\
\hline $\begin{array}{l}\text { Cumberland (including } \\
\text { the Green River basin } \\
\text { in Tennessee) }\end{array}$ & $\begin{array}{l}\text { Upper Cumberland } \\
\text { Obey } \\
\text { Caney } \\
\text { Lower Cumberland } \\
\text { Harpeth } \\
\text { Stones } \\
\text { Red }\end{array}$ & $\begin{array}{l}\text { Central Basin } \\
\text { Highland Rim } \\
\text { Cumberland } \\
\quad \text { Plateau }\end{array}$ & $\begin{array}{l}\text { Many small unregulated } \\
\text { streams. Area } \\
\text { characterized by no } \\
\text { flow or low flow } \\
\text { during dry periods. } \\
\text { The Cumberland } \\
\text { River is regulated. }\end{array}$ & $\begin{array}{l}\text { In the Central Basin, } \\
\text { streamflow is highly } \\
\text { responsive to rainfall } \\
\text { and flows are poorly } \\
\text { sustained. Stramflows } \\
\text { are fairly well sustained } \\
\text { in the Highland Rim. } \\
\text { The streamflows in } \\
\text { the Cumberland River } \\
\text { Plateau are poorly } \\
\text { sustained. }\end{array}$ \\
\hline Lower Tennessee & $\begin{array}{l}\text { Lower Tennessee } \\
\text { Duck } \\
\text { Buffalo } \\
\text { Beach } \\
\text { Big Sandy }\end{array}$ & $\begin{array}{l}\text { Highland Rim } \\
\text { Central Basin } \\
\text { Western Valley }\end{array}$ & $\begin{array}{l}\text { In late summer and } \\
\text { early fall, unregulated } \\
\text { streams go dry or } \\
\text { sustain low flows. }\end{array}$ & $\begin{array}{l}\text { In the Central Basin, } \\
\text { streamflow is highly } \\
\text { responsive to rainfall } \\
\text { and flows are poorly } \\
\text { sustained. Straamflows } \\
\text { are fairly well sustained } \\
\text { in the Highland } \\
\text { Rim. Streamflow is } \\
\text { adequately sustained } \\
\text { for supply in the } \\
\text { Western Valley. }\end{array}$ \\
\hline
\end{tabular}


Table 1. Surface-water characteristics of the hydrologic subregions and major river basins in Tennessee.-Continued

[From Webbers (2003)]

\begin{tabular}{|c|c|c|c|c|}
\hline Hydrologic subregion' & $\begin{array}{l}\text { Major river basin and } \\
\text { associated streams }\end{array}$ & $\begin{array}{l}\text { Physiographic divisions } \\
\text { (Miller, 1974) }\end{array}$ & Response to drought & Remarks \\
\hline Middle Tennessee-Elk & $\begin{array}{l}\text { Middle Tennessee-Elk } \\
\text { Elk } \\
\text { Shoal } \\
\text { Flint }\end{array}$ & $\begin{array}{l}\text { Highland Rim } \\
\text { Cumberland Plateau } \\
\text { Central Basin }\end{array}$ & $\begin{array}{l}\text { Commonly in late } \\
\text { summer, unregulated } \\
\text { streams go dry, } \\
\text { particularly along the } \\
\text { basin rim. }\end{array}$ & $\begin{array}{l}\text { In the Central Basin, } \\
\text { streamflow is highly } \\
\text { responsive to rainfall } \\
\text { and flows are poorly } \\
\text { sustained. Streamflows } \\
\text { are fairly well sustained } \\
\text { in the Highland Rim. } \\
\text { In the Cumberland } \\
\text { Plateau, streamflows } \\
\text { are poorly sustained. }\end{array}$ \\
\hline Upper Tennessee & $\begin{array}{l}\text { French Broad-Holston } \\
\text { French Broad } \\
\text { Holston } \\
\text { Nolichucky } \\
\text { Upper Tennessee } \\
\text { Clinch } \\
\text { Powell } \\
\text { Little Tennessee } \\
\text { Little } \\
\text { Tellico }\end{array}$ & $\begin{array}{l}\text { Blue Ridge } \\
\text { Valley and Ridge } \\
\text { Cumberland Plateau }\end{array}$ & $\begin{array}{l}\text { Commonly in late } \\
\text { summer, unregulated } \\
\text { streams go dry. Many } \\
\text { small unregulated } \\
\text { streams may sustain } \\
\text { low flow with } \\
\text { groundwater inflow. }\end{array}$ & $\begin{array}{l}\text { In the Blue Ridge, } \\
\text { steep terrain and low } \\
\text { permeability result } \\
\text { in high runoff rates. } \\
\text { Many springs are in } \\
\text { the area. Surface-water } \\
\text { impoundments enhance } \\
\text { water supplies in the } \\
\text { Valley and Ridge. In } \\
\text { the Cumberland } \\
\text { Plateau, streamflows } \\
\text { are poorly sustained. }\end{array}$ \\
\hline $\begin{array}{l}\text { Middle Tennessee- } \\
\text { Hiwassee (including } \\
\text { the Alabama region) }\end{array}$ & $\begin{array}{l}\text { Middle Tennessee- } \\
\text { Hiwassee } \\
\text { Hiwassee } \\
\text { Sequatchie }\end{array}$ & $\begin{array}{l}\text { Blue Ridge } \\
\text { Valley and Ridge } \\
\text { Cumberland Plateau } \\
\text { Sequatchie Valley }\end{array}$ & $\begin{array}{l}\text { Commonly in late } \\
\text { summer, unregulated } \\
\text { streams go dry, } \\
\text { particularly along the } \\
\text { basin rim. Even } \\
\text { streams having water- } \\
\text { sheds exceeding } \\
100 \text { square miles } \\
\text { may cease to flow. }\end{array}$ & $\begin{array}{l}\text { In the Blue Ridge, } \\
\text { steep terrain and low } \\
\text { permeability result in } \\
\text { high runoff } \\
\text { rates. Many springs are } \\
\text { in the area. Surface- } \\
\text { water impoundments } \\
\text { enhance water supplies } \\
\text { in the Valley and Ridge. } \\
\text { In the Cumberland } \\
\text { Plateau, streamflows } \\
\text { are poorly sustained. }\end{array}$ \\
\hline
\end{tabular}

${ }^{1}$ Refer to figure 1 for location on map.

${ }^{2}$ South Atlantic-Gulf Region extending from Alabama.. 


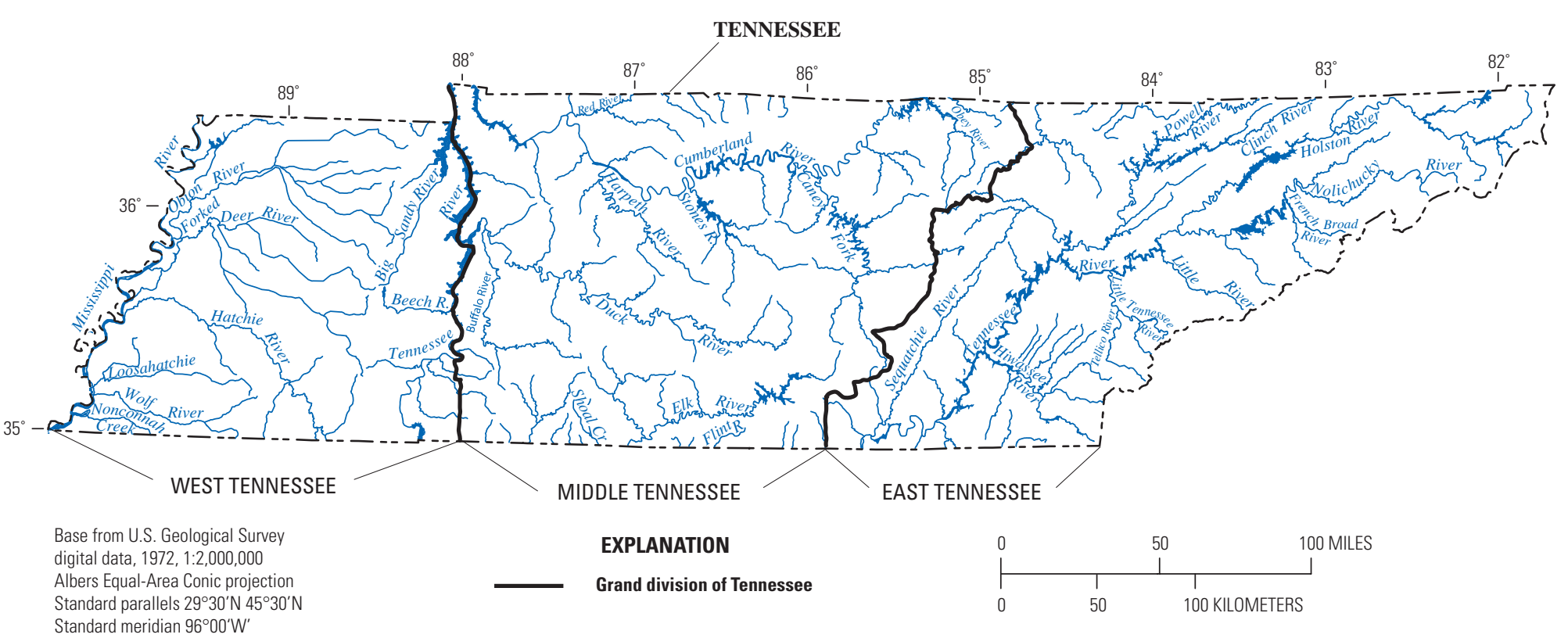

Figure 3. Primary tributaries of the Mississippi, Tennessee, and Cumberland Rivers in Tennessee.
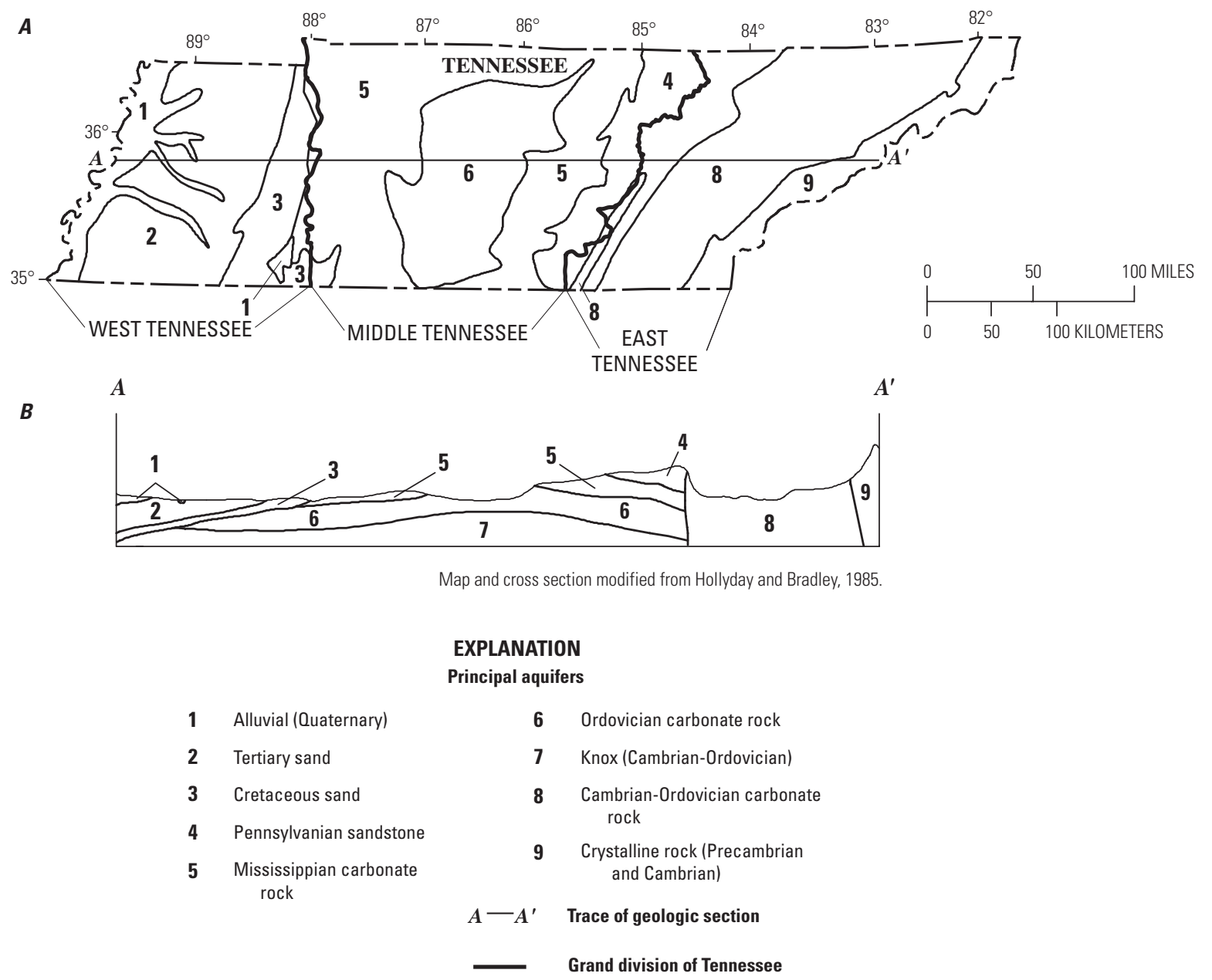

Note: Schematic not to scale.

Figure 4. Principal aquifers and generalized geologic section in Tennessee. Modified from Webbers (2003). $A$, State of Tennessee; and, $B$, cross section $A-A^{\prime}$. 
Table 2. Aquifer and well characteristics in Tennessee.

[Modified from Hollyday and Bradley (1985)]

\begin{tabular}{|c|c|c|c|c|c|}
\hline \multirow{3}{*}{ Aquifer name ${ }^{1}$ and description } & \multicolumn{4}{|c|}{ Well characteristics } & \multirow{3}{*}{ Remarks } \\
\hline & \multicolumn{2}{|c|}{$\begin{array}{l}\text { Depth, } \\
\text { in feet }\end{array}$} & \multicolumn{2}{|c|}{$\begin{array}{c}\text { Yield, in } \\
\text { gallons per minute }\end{array}$} & \\
\hline & $\begin{array}{l}\text { Common } \\
\text { range }\end{array}$ & $\begin{array}{c}\text { May } \\
\text { exceed }\end{array}$ & $\begin{array}{l}\text { Common } \\
\text { range }\end{array}$ & $\begin{array}{c}\text { May } \\
\text { exceed }\end{array}$ & \\
\hline $\begin{array}{l}\text { Alluvial: Sand, gravel, and clay. } \\
\text { Unconfined. }\end{array}$ & $10-75$ & 100 & $20-50$ & 1,500 & High iron concentrations in some areas. \\
\hline $\begin{array}{l}\text { Tertiary sand: Multiaquifer unit of sand, } \\
\text { clay, silt, and some gravel lignite. } \\
\text { Confined; unconfined in the outcrop } \\
\text { area. }\end{array}$ & $100-1,300$ & 1,500 & $200-1,000$ & 2,000 & $\begin{array}{l}\text { Includes Memphis Sand of Claiborne Group } \\
\text { and Fort Pillow Sand of Wilcox Group. } \\
\text { Problems with high iron concentration in } \\
\text { some places. }\end{array}$ \\
\hline $\begin{array}{l}\text { Cretaceous sand: Multiaquifer unit of } \\
\text { interbedded sand, clay, marl, and } \\
\text { gravel. Confined; unconfined in the } \\
\text { outcrop area. }\end{array}$ & $100-1,500$ & 2,500 & $50-1,000$ & 1,000 & $\begin{array}{l}\text { Includes McNairy and Coffee Sands and } \\
\text { Tuscaloosa Formation. Water withdrawn } \\
\text { primarily in the outcrop area. }\end{array}$ \\
\hline $\begin{array}{l}\text { Pennsylvanian sandstone: Multiaquifer } \\
\text { unit, primarily sandstone and } \\
\text { conglomerate, interbedded shale and } \\
\text { some coal. Unconfined near land } \\
\text { surface; confined at depth. }\end{array}$ & $100-200$ & 250 & $5-50$ & 200 & $\begin{array}{l}\text { Permeability is from fractures, faults, and } \\
\text { bedding-plane openings. Principal water- } \\
\text { bearing units are Rockcastle and Sewanee } \\
\text { Conglomerates. High iron concentrations } \\
\text { are a problem. }\end{array}$ \\
\hline $\begin{array}{l}\text { Mississippian carbonate rock: } \\
\text { Multiaquifer unit of limestone, } \\
\text { dolomite, and some shale. } \\
\text { Unconfined or partly confined near land } \\
\text { surface; may be confined at depth. }\end{array}$ & $50-200$ & 250 & $5-50$ & 400 & $\begin{array}{l}\text { Water occurs in solution and bedding-plane } \\
\text { openings. Principal water-bearing units } \\
\text { are Ste. Genevieve (Monteagle), St. Louis } \\
\text { and Warsaw Limestone and Fort Payne } \\
\text { Formation. Water generally hard; high } \\
\text { iron, sulfide, or sulfate concentration are a } \\
\text { problem in some areas. }\end{array}$ \\
\hline $\begin{array}{l}\text { Ordovician carbonate rock: Multiaquifer } \\
\text { unit of limestone, dolomite, and shale. } \\
\text { Partly confined to unconfined near land } \\
\text { surface; confined at depth. }\end{array}$ & $50-150$ & 200 & $5-20$ & 300 & $\begin{array}{l}\text { Principal water-bearing units are Bigby, } \\
\text { Carters, Ridley, and Murfreesboro } \\
\text { Limestones. Water generally hard; some } \\
\text { high sulfide or sulfate concentrations } \\
\text { in places. }\end{array}$ \\
\hline $\begin{array}{l}\text { Knox: Primarily dolomite, some } \\
\text { limestone; confined. Does not have the } \\
\text { structural complexity of the Cambrian- } \\
\text { Ordovician carbonate aquifer. }\end{array}$ & $700-1,200$ & 1,400 & $1-10$ & 20 & $\begin{array}{l}\text { Deep aquifer; present beneath most of } \\
\text { central and western Tennessee. Away from } \\
\text { Central Basin,water generally has high } \\
\text { concentrations of dissolved solids. }\end{array}$ \\
\hline $\begin{array}{l}\text { Cambrian-Ordovician carbonate rock: } \\
\text { Highly faulted multiaquifer unit } \\
\text { of limestone, dolomite, sandstone, } \\
\text { and shale; structurally complex. } \\
\text { Unconfined; confined at depth. }\end{array}$ & $100-300$ & 400 & $5-200$ & 2,000 & $\begin{array}{l}\text { Principal water-bearing units are carbonate } \\
\text { rocks in Chickamauga Limestone, Knox } \\
\text { Group, and Honaker Dolomite. Water is } \\
\text { generally hard. Brine below 3,000 feet. }\end{array}$ \\
\hline $\begin{array}{l}\text { Crystalline rock: Multiaquifer unit of } \\
\text { dolomite, granite gneiss, phyllite, and } \\
\text { metasedimentary rocks overlain by } \\
\text { thick regolith; alluvium and colluvium } \\
\text { in some valleys. Generally unconfined. }\end{array}$ & $50-150$ & 200 & $5-20$ & 1,000 & $\begin{array}{l}\text { High yields occur primarily in dolomite } \\
\text { or deep colluvium and alluvium. Shady } \\
\text { Dolomite is a principal water bearing unit. } \\
\text { Low pH and high iron concentrations may } \\
\text { be problems in some areas. }\end{array}$ \\
\hline
\end{tabular}

${ }^{1}$ Refer to figure 4 for location on map. 


\section{Physiographic Regions}

Information on physiographic regions presented in this section is from Webbers (2003) unless cited otherwise. The diverse topography of Tennessee includes eight physiographic regions (fig. 1) that range from broad flood plains in the Coastal Plain physiographic region of West Tennessee, to rolling hills and karst plains in the Highland Rim and Central Basin regions of Middle Tennessee, and to steep mountains and deep narrow valleys in the Valley and Ridge and Blue Ridge regions of East Tennessee. The geology of Tennessee includes unconsolidated Quaternary, Tertiary, and Cretaceous sediments of the Coastal Plain in West Tennessee; Mississippian and Ordovician limestone and dolomite of the Highland Rim and Central Basin in Middle Tennessee; and Pennsylvanian limestone, sandstone, and shale of the Cumberland Plateau, Cambrian-Ordovician limestone, dolomite, and shale in the Valley and Ridge region, and Precambrian and Cambrian metamorphic and igneous crystalline rocks of the Blue Ridge region in East Tennessee (Miller, 1974).

\section{Previous Investigations}

Information on previous investigations presented in this section is from Webbers (2003) unless cited otherwise. Previous investigations have been published with water-use data for Tennessee as part of a national compilation since the 1950s (MacKichan, 1951, 1957; MacKichan and Kammerer, 1961; Murray, 1968; Murray and Reeves, 1972, 1977; Solley and others, 1993) and specific to Tennessee since the 1980s (Alexander and others, 1984; Hutson, 1989, 1991, 1999; Hutson and Morris, 1992, 1994; Webbers, 2003; Robinson and
Brooks, 2010). The most recent investigation for self-supplied industrial water use in Tennessee was by Alexander and others (1984).

Since 1950, the USGS has published reports documenting public-supply water systems and associated water-use data for Tennessee. During 1950 to 1985, total public-supply water demand trends in Tennessee seemed to be attributed to a natural shift in demand that is a function of population growth, income growth, and economic development (Griffin, 2006) when tracked at 5-year intervals. During 1985 to 2010, it is more challenging to determine the effect of growth, development factors, a climate factor, a policy factor, or a combination of $n$-factors on total public-supply water demand trends in Tennessee or for public-supply water use. The combined public-supply system withdrawals of groundwater and surface water were estimated at $160 \mathrm{Mgal} / \mathrm{d}$ in 1950; groundwater withdrawals were estimated to be $85 \mathrm{Mgal} / \mathrm{d}$, and surface-water withdrawals were estimated to be $75 \mathrm{Mgal} / \mathrm{d}$ (MacKichan, 1951) (fig. 5). In 1955, total public-supply system water withdrawals for Tennessee were estimated at $250 \mathrm{Mgal} / \mathrm{d}$ (MacKichan, 1957). By 1975, total public-supply system water withdrawals had reached about $440 \mathrm{Mgal} / \mathrm{d}$ (Murray and Reeves, 1977). From 1988 (Hutson and Morris, 1992) to 1990 (Hutson and Morris, 1994), surface-water withdrawals decreased slightly from 446 to $426 \mathrm{Mgal} / \mathrm{d}$. Groundwater withdrawals in the State, however, increased slightly during the same time period from $262 \mathrm{Mgal} / \mathrm{d}$ (Hutson and Morris, 1992) to $269 \mathrm{Mgal} / \mathrm{d}$ (Solley and others, 1993). In 1995, total withdrawals by public-supply water systems reached $779 \mathrm{Mgal} / \mathrm{d}$ (Hutson, 1999), and there was an additional increase of 13 percent in 2000 (890 Mgal/d) (Webbers, 2003). The withdrawal rates of water systems distributing public supply in Tennessee increased from $890 \mathrm{Mgal} / \mathrm{d}$ in 2000 (Webbers, 2003) to $917 \mathrm{Mgal} / \mathrm{d}$ in 2010.

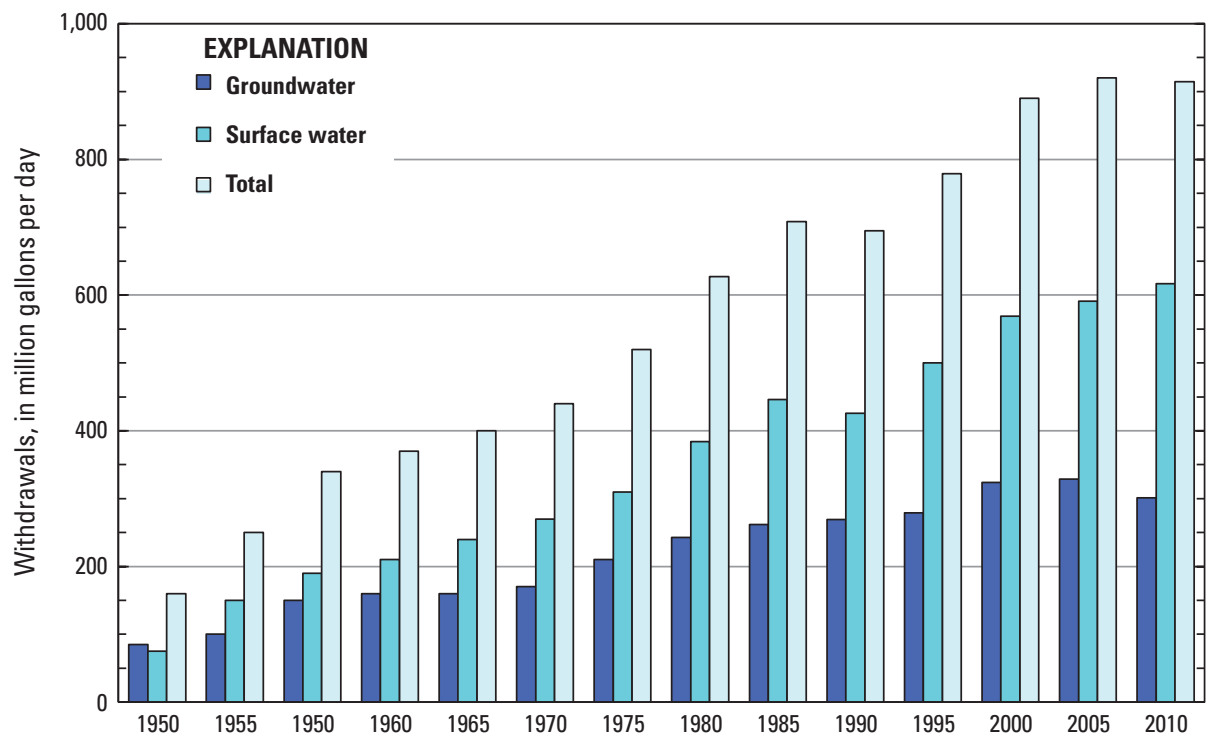

Figure 5. Surface-water and groundwater withdrawals by public-supply water systems in Tennessee, 1950 to 2010 (MacKichan, 1951, 1957; MacKichan and Kammerer, 1961; Murray, 1968; Murray and Reeves, 1972, 1977; Solley and others, 1993; Alexander and others, 1984; Hutson, 1989, 1999; Hutson and Morris, 1992, 1994; Webbers, 2003; Robinson and Brooks, 2010). 


\section{Approach and Methods}

To assess public-supply water use in Tennessee, data were collected and analyzed for public-supply water systems active between January 1 and December 31, 2010. The public-supply water systems included investor-owned water companies, private water companies, municipal water departments, regional water authorities, residential developments, mobile home parks, homeowner associations, and institutions such as schools and prisons. Each water system supplied the TDEC-DWR with monthly operating reports that included information on the source of water, mean daily or monthly water withdrawal rates, and the population served. In some instances, public-supply water systems were contacted to supplement missing data or verify reported data. In previous and current public-supply studies, the USGS labeled the monthly operating report data as water withdrawals - a surrogate for potable water produced (Hutson, 1999; Webbers, 2003; and Robinson and Brooks, 2010).

Monthly and annual average water withdrawals by each public-supply water system were separated into categories of surface water, groundwater, and purchased water. The withdrawal rates of systems using surface-water and groundwater supplies were calculated and compared to historic withdrawal rates and with changes in the population served. The amounts of water purchased or sold by publicsupply water systems are not included in the calculations for the amount of water withdrawn from the river basins or aquifers.

To assess self-supplied industrial water use in Tennessee, data were collected and analyzed for industrial water users active between January 1 and December 31, 2010. The industrial water users used water for purposes such as fabrication, processing, washing, diluting, cooling, or transporting a product; incorporating water into a product; or for sanitation needs within a manufacturing facility (Maupin and others, 2014). Industries that use large amounts of water produce commodities such as chemicals, food, metals, paper, or refined petroleum. Each industrial water user supplied the TDEC-DWR with monthly reports that included information on the source of water and mean monthly water withdrawal rates. The TDEC-DWR receives golf course water-use information, but these values are not included in this report because the USGS accounts for golf course water use within the irrigation water-use category.

Monthly and annual average water withdrawals of each self-supplied industry were separated into categories of surface water and groundwater. The withdrawal rates of industries using surface-water and groundwater supplies were calculated and compared with historic withdrawal rates.

A USGS data release (Robinson, 2017) documents the data used to support the findings in this report with a specific focus on the net supply and gross per capita water use and the amount of self-supplied industrial water used by county in each hydrologic region. In addition to providing the data in a digital format (Robinson, 2017), the data are presented in tables (appendixes 1-7) available for download at https://doi. org/10.3133/sir20185009.

\section{Public-Supply Water Use During 2010}

During 2010, public-supply water systems of Tennessee withdrew $917 \mathrm{Mgal} / \mathrm{d}$ of water, which is a combined withdrawal of 67 percent surface water (617 Mgal/d) and 33 percent groundwater (300 Mgal/d) (fig. 6). Public-supply water systems may use a stream or reservoir as a surfacewater source, water withdrawn from a well or spring as a groundwater source, or purchased water from another water system. In 2010, about 89 percent (5.7 million people) of Tennessee's population was served by 474 public-supply water systems. Several of these public-supply water systems (131) relied entirely on water purchased from other water systems providing $74.7 \mathrm{Mgal} / \mathrm{d}$ of purchased water to Tennessee residents. A review of previous investigations describing water use by public-supply water systems in Tennessee from 1950 to 2010 indicates that surface-water sources provided most of Tennessee's public supply in 2010 and that surface-water withdrawals have increased steadily, whereas groundwater withdrawals have leveled off (2000-2005) or declined (2005-2010) (fig. 5).

Of the 343 public-supply water systems withdrawing water (not relying entirely on purchased water), 126 systems withdrew surface water, 201 systems withdrew groundwater, and 16 systems withdrew both (fig. 7). Information about the water source(s) for each public-supply water system, including the amount of water withdrawn, purchased, or sold; the population served by each system; and the gross per capita water use for each system for which such information is known, is provided in appendixes 1, 2, and 3. A list of the public-supply water systems in Tennessee in 2010 is provided in appendix 7.

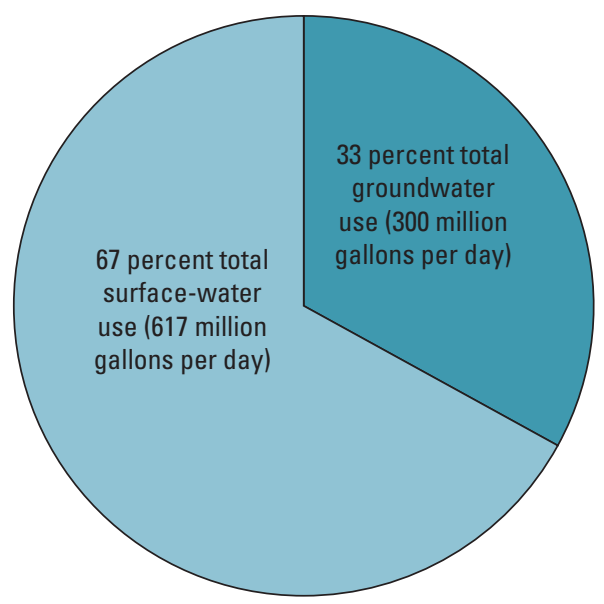

Figure 6. Source of water use for publicsupply water systems in Tennessee in 2010. 


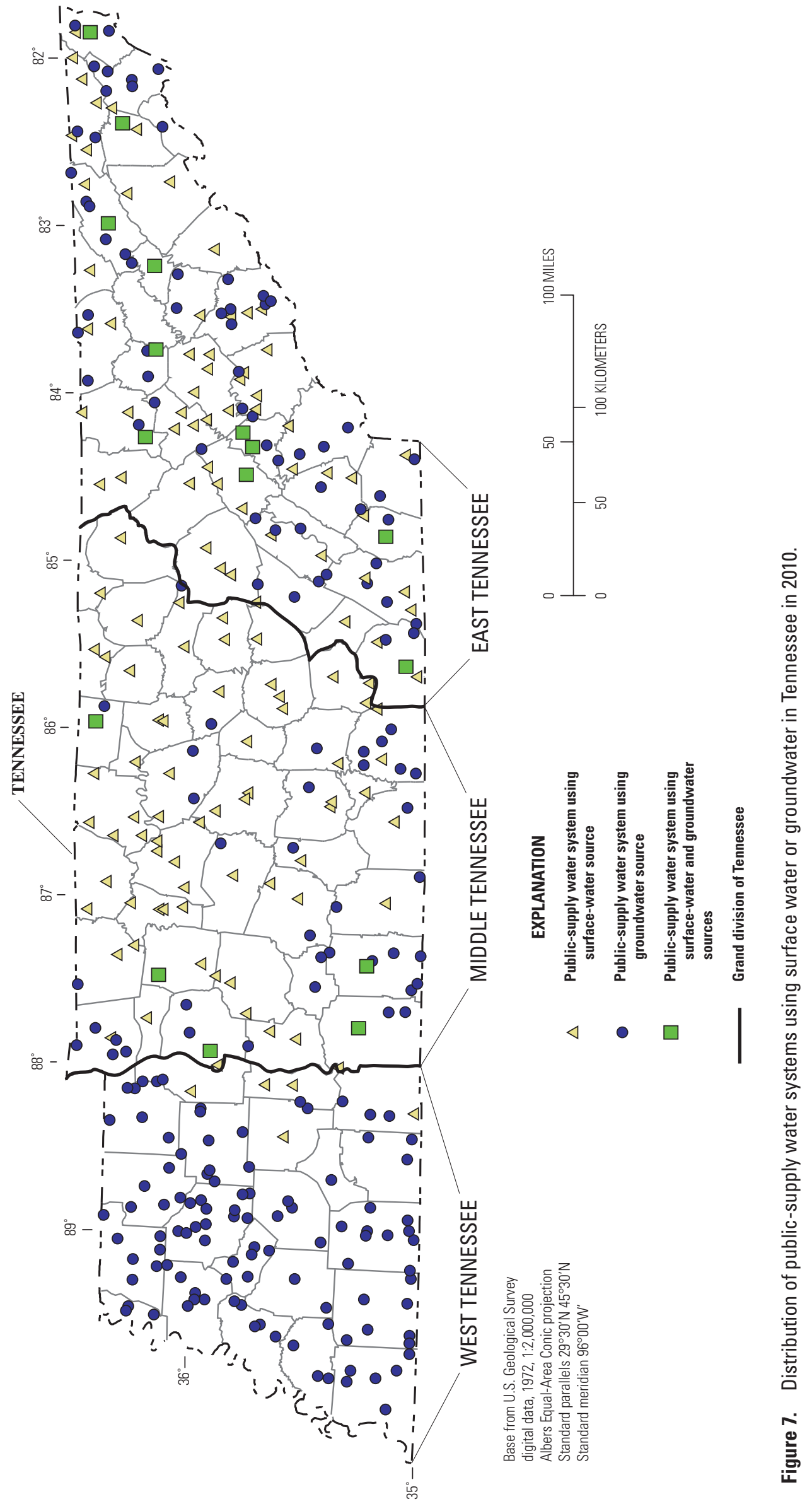


Each of the 95 counties in Tennessee was served by at least one public-supply water system in 2010 (fig. 7). The largest groundwater withdrawal rate (151 Mgal/d) by a single public-supply water system was reported by Memphis Light, Gas and Water (MLGW), which served more than 669,000 people in Shelby County in 2010 (appendix 3). The county with the largest surface-water withdrawal rate (136 Mgal/d) was Davidson County (appendix 2).

\section{Surface Water}

In 2010, surface water provided about two-thirds of the total public supply distributed by water systems in Tennessee (fig. 6). This quantity represents an increase of $26 \mathrm{Mgal} / \mathrm{d}$ (4 percent) more than the $591 \mathrm{Mgal} / \mathrm{d}$ (fig. 5) reported for 2005 (Robinson and Brooks, 2010). In 2010, 93 public-supply water systems withdrew surface-water supplies of $1 \mathrm{Mgal} / \mathrm{d}$ or more. The largest public-supply withdrawals from surface water by hydrologic region (fig. 1) in the State were in counties in the Tennessee and Ohio hydrologic regions; and came primarily from the Lower Cumberland (244 Mgal/d), Upper Tennessee (125 Mgal/d), French Broad-Holston (78.9 Mgal/d), and Middle Tennessee-Hiwassee (75.7 Mgal/d) River Basins. Other river basins in Tennessee provided 93.4 Mgal/d of the public supply in 2010 (table 3).

Surface-water withdrawals for public supply in 2010 were concentrated in Middle and East Tennessee (fig. 8). Water-supply systems serving the metropolitan Nashville/ Davidson County area served more than 616,000 customers

Table 3. Surface-water withdrawals by public-supply water systems from Tennessee river basins in 2010.

\begin{tabular}{lc}
\hline \multicolumn{1}{c}{ River basin name } & $\begin{array}{c}\text { Surface-water } \\
\text { withdrawal rate, } \\
\text { in million gallons } \\
\text { per day }\end{array}$ \\
\hline Lower Cumberland & 244 \\
Upper Tennessee & 125 \\
French Broad-Holston & 78.9 \\
Middle Tennessee-Hiwassee & 75.7 \\
Lower Tennessee & 43.3 \\
Upper Cumberland & 39.1 \\
Middle Tennessee-Elk & 10.2 \\
Hatchie-Obion & 0.770 \\
\hline
\end{tabular}

in 2010 and withdrew $136 \mathrm{Mgal} / \mathrm{d}$ from the Cumberland River (appendix 2). This was the largest surface-water withdrawal in the State during 2010. Large amounts of surface water were also withdrawn from the Tennessee River in the Chattanooga (Hamilton County) and Knoxville (Knox County) metropolitan areas (appendix 1). Because of the abundance and availability of groundwater supplies (Hutson and Morris, 1992; Hutson, 1999), surface water was not a primary source for public-supply water systems in West Tennessee. Additional information about surface-water sources and withdrawal rates are presented in appendixes 1,2 , and 3 .

\section{Groundwater}

In 2010, groundwater provided about one-third of the total public supply distributed by water systems in Tennessee. Groundwater supplied $300 \mathrm{Mgal} / \mathrm{d}$ in 2010 (fig. 5), which was a decrease of $29 \mathrm{Mgal} / \mathrm{d}$ since 2005. This decrease was the first decrease in groundwater withdrawals since 1950. From 2005 to 2010 more than 55 percent (16.1 Mgal/d) of this decrease in groundwater withdrawals happened in Memphis by MLGW in Shelby County, Tennessee. Almost 78 percent of the groundwater withdrawn for public supply during 2010 was in West Tennessee. In Shelby County, Tennessee, groundwater withdrawals yielded $173 \mathrm{Mgal} / \mathrm{d}$ (fig. 9) and provided water for more than 809,000 people. The largest total withdrawal (151 Mgal/d) by a single water system in Tennessee happened in Memphis by MLGW, which served a population of over 669,000. About $235 \mathrm{Mgal} / \mathrm{d}$ of groundwater were withdrawn from the Tertiary sand, Cretaceous sand, and alluvial aquifers (figs. 10 and 11). In contrast to the large amount of groundwater used in West Tennessee, the combined withdrawals from aquifers in Middle and East Tennessee were $65 \mathrm{Mgal} / \mathrm{d}$.

A review of historical groundwater use reported by large public-supply water systems (Robinson and Brooks, 2010) withdrawing $1 \mathrm{Mgal} / \mathrm{d}$ or more in Tennessee from 1988 through 2010 indicates that, within the 23-year period, withdrawal rates increased substantially for several of these systems (table 4). During this same time, 29 systems reported increased withdrawals, and 12 of these systems increased withdrawals by more than $1 \mathrm{Mgal} / \mathrm{d}$. The greatest total increase in withdrawal rates was reported by systems located in the Lower Mississippi hydrologic region of West Tennessee (22.87 Mgal/d). A total of 50 percent (151 Mgal/d) of the groundwater withdrawals in 2010 were by MLGW, which reported an increase of $9.77 \mathrm{Mgal} / \mathrm{d}$ in withdrawals since 1988. 


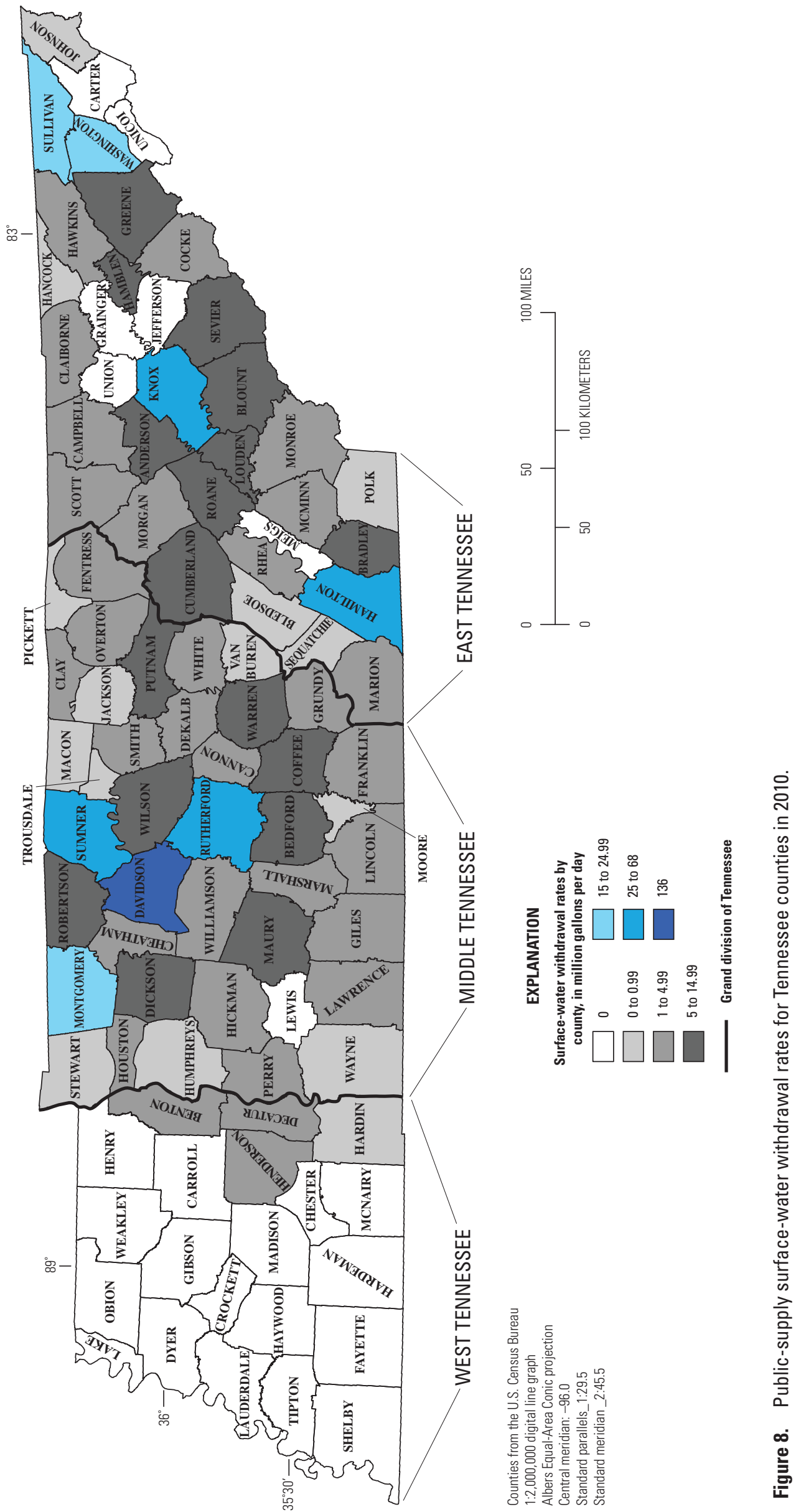




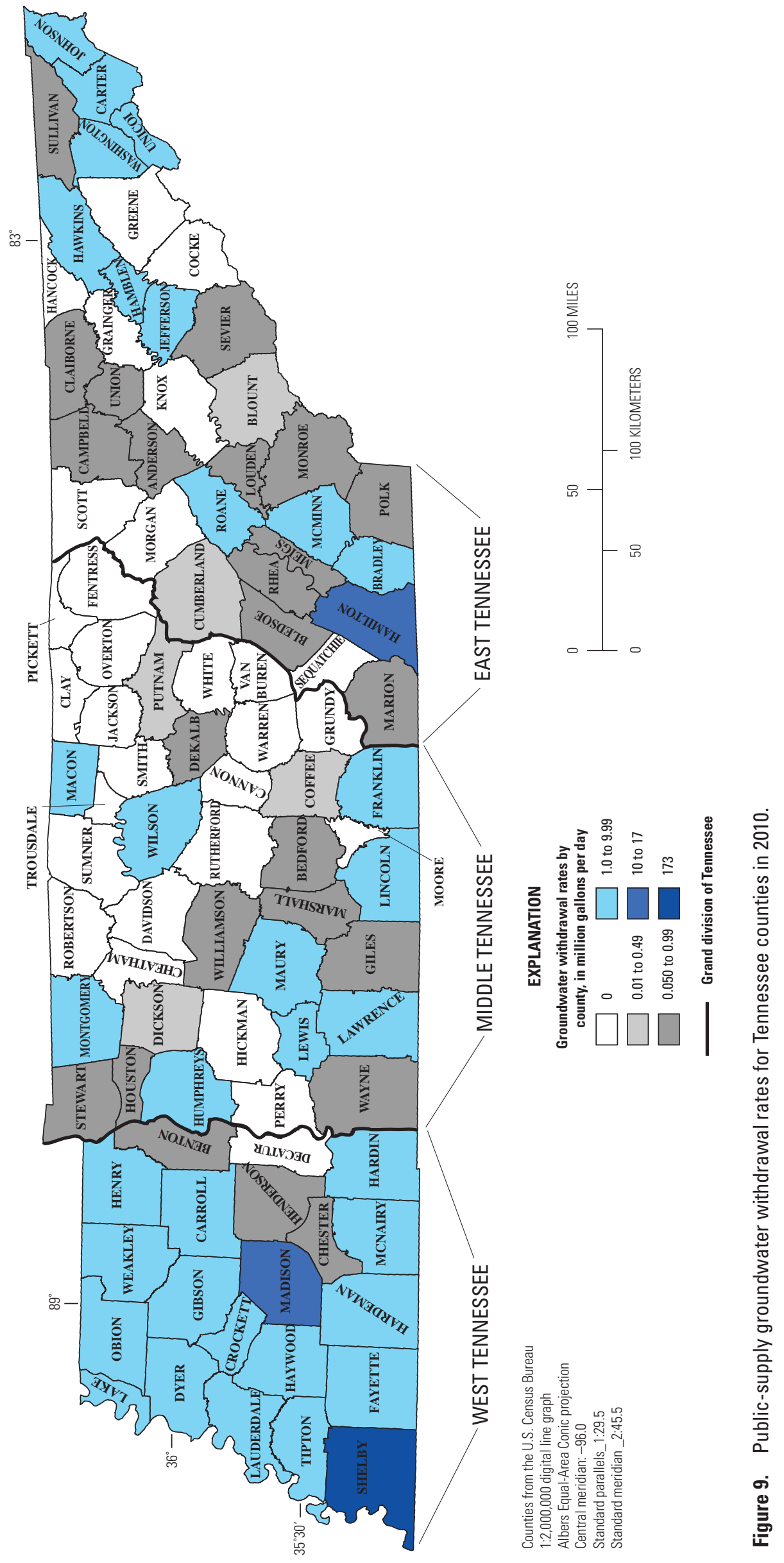




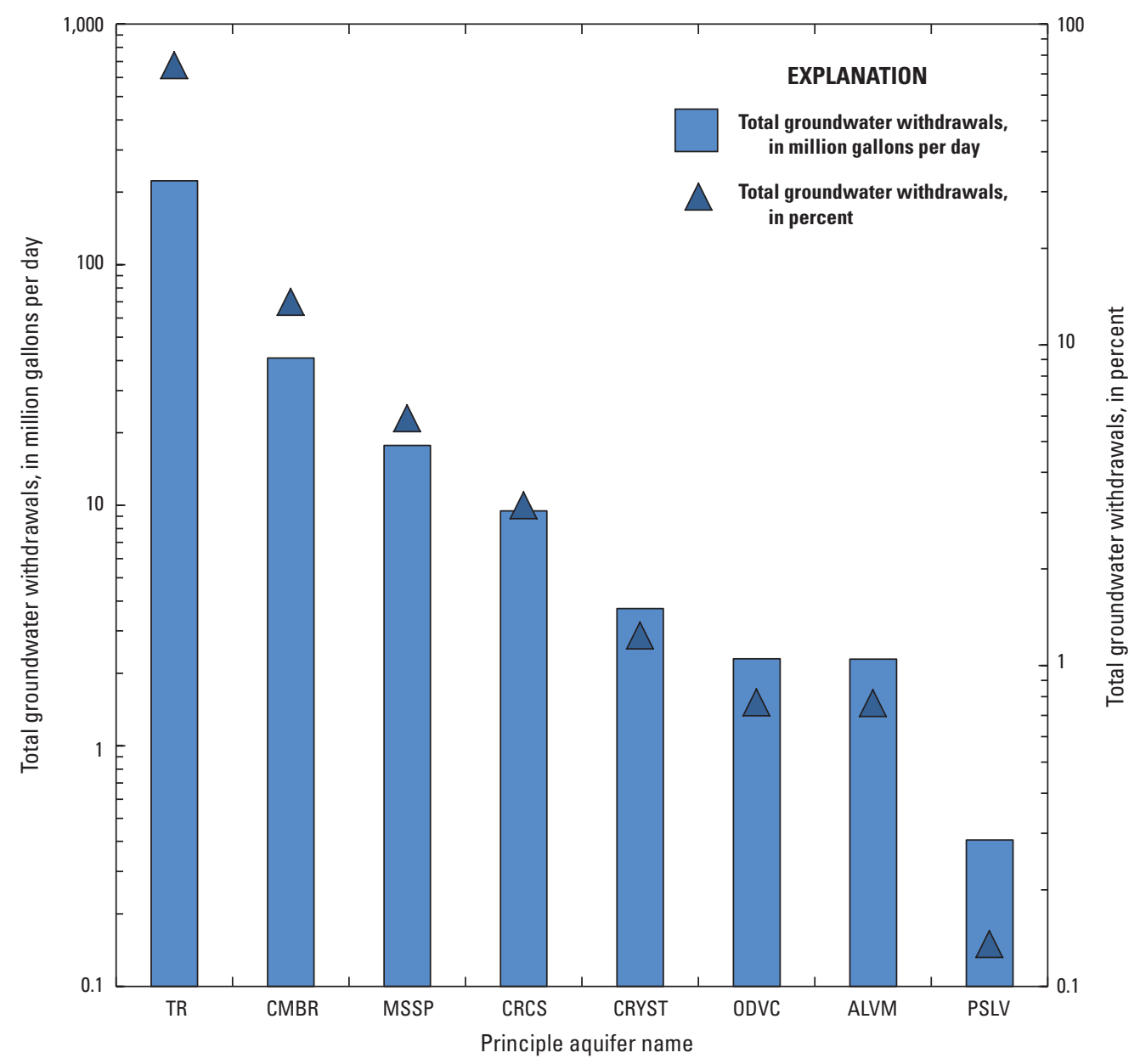

EXPLANATION

Principal aquifer name

$\begin{array}{clll}\text { TR } & \text { Tertiary sand } & \text { ODVC } & \text { Ordovician carbonate rock } \\ \text { CMBR } & \text { Cambrian-Ordovician carbonate rock } & \text { ALVM } & \text { Alluvial (Quaternary) } \\ \text { MSSP } & \text { Mississippian carbonate rock } & \text { PSLV } & \text { Pennsylvanian sandstone } \\ \text { CRCS } & \text { Cretaceous sand } & & \\ \text { CRYST } & \text { Crystalline rock (Precambrian and Cambrian } & & \end{array}$

Figure 10. Public-supply groundwater withdrawals, in million gallons per day, from principal aquifers in Tennessee in 2010. 


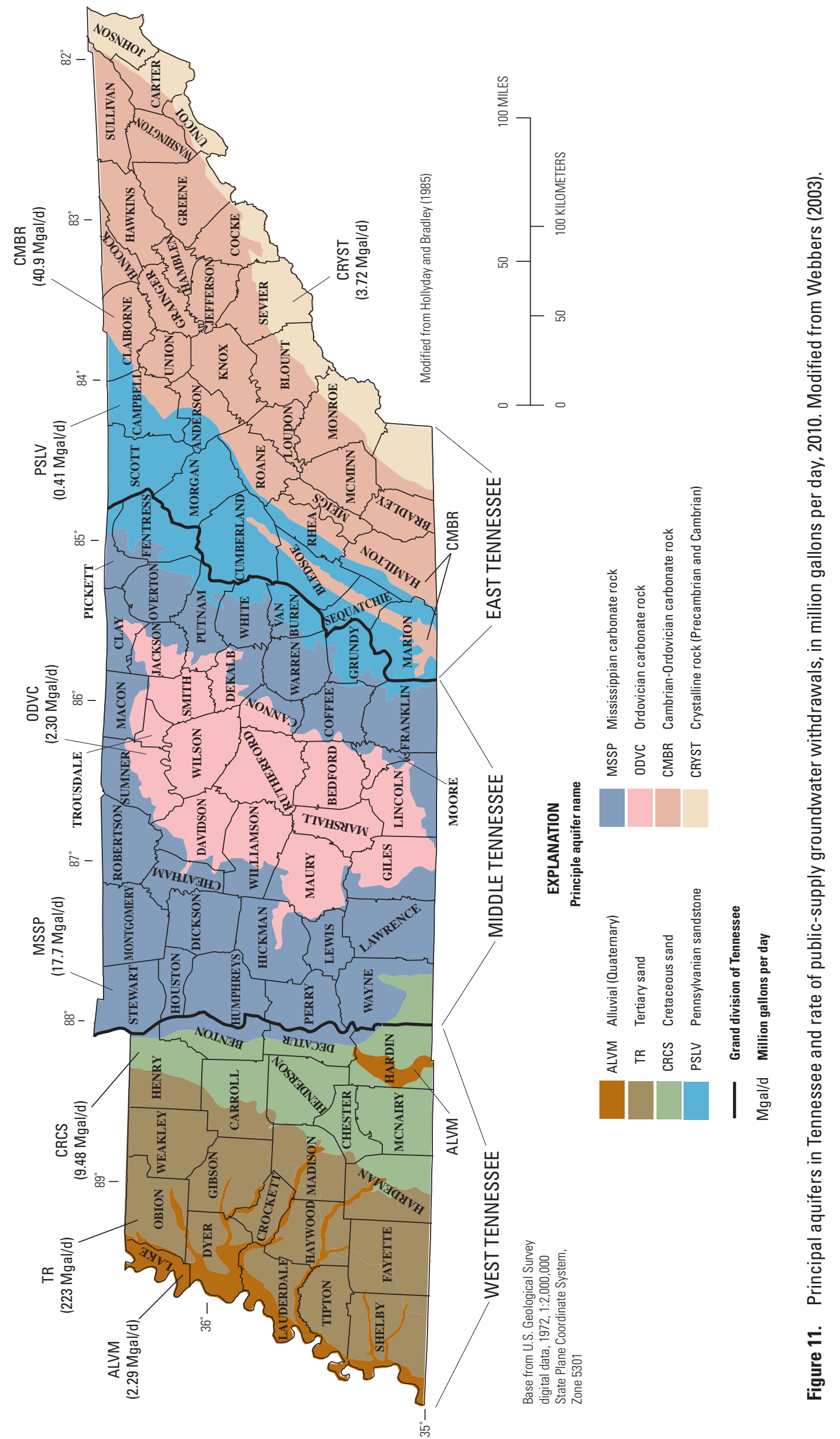


Table 4. Groundwater withdrawals by public-supply water systems in Tennessee using 1 million gallons per day or more.

[TRMS, Tertiary sand-Memphis aquifer; CRCS, Cretaceous sand; TRCF, Tertiary sand-Cockfield aquifer; TRFP, Tertiary sand-Fort Pillow aquifer; CMBR, Cambrian-Ordovician carbonate rock; CRYST, Crystalline rock; ALVM, Alluvial; MSSP, Mississippian carbonate; ODVC, Ordovician carbonate rock;-, no groundwater withdrawal reported by system; N/A, not applicable]

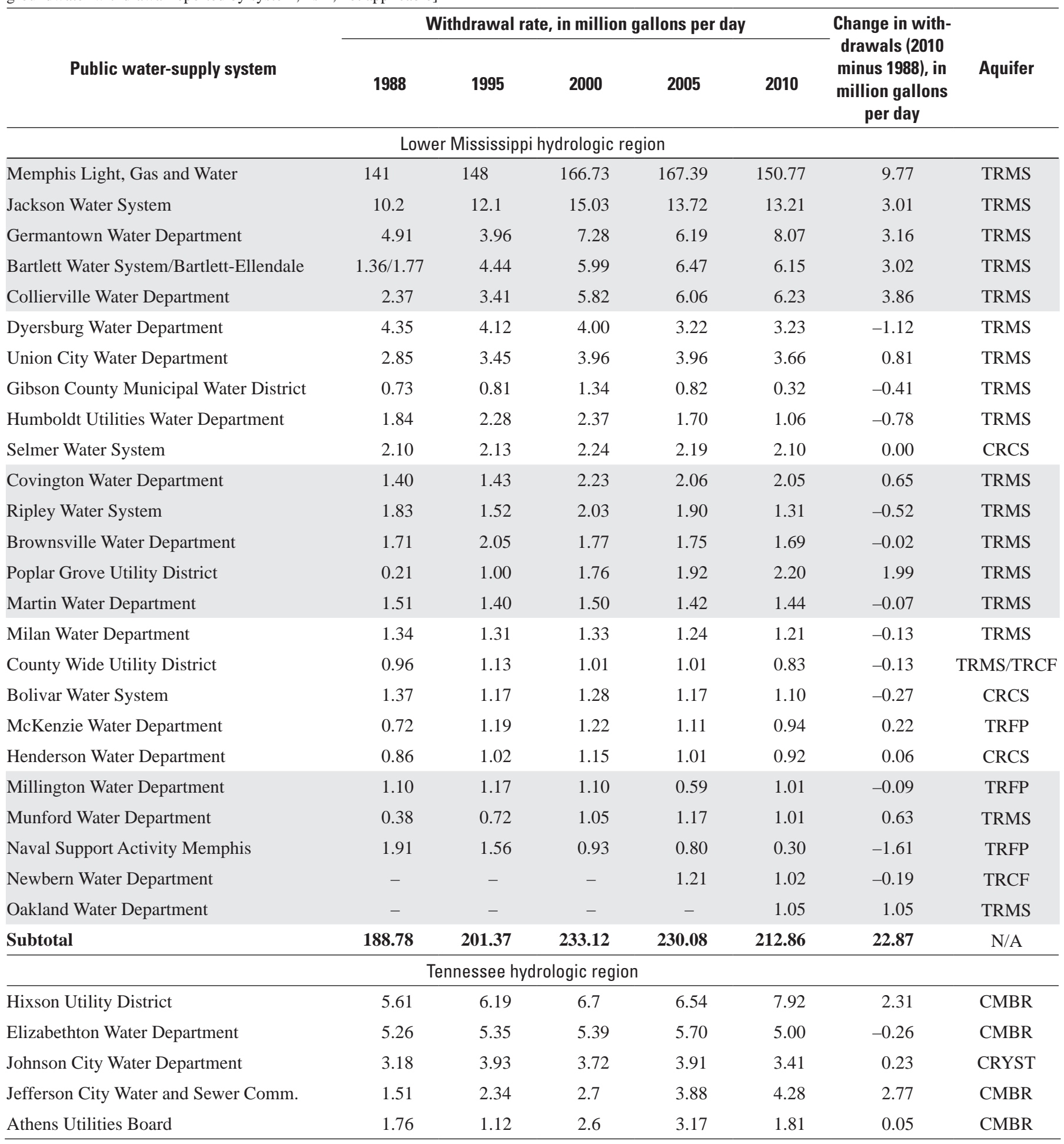


Table 4. Groundwater withdrawals by public-supply water systems in Tennessee using 1 million gallons per day or more.-Continued

[TRMS, Tertiary sand-Memphis aquifer; CRCS, Cretaceous sand; TRCF, Tertiary sand-Cockfield aquifer; TRFP, Tertiary sand-Fort Pillow aquifer; CMBR, Cambrian-Ordovician carbonate rock; CRYST, Crystalline rock; ALVM, Alluvial; MSSP, Mississippian carbonate; ODVC, Ordovician carbonate rock;-, no groundwater withdrawal reported by system; N/A, not applicable]

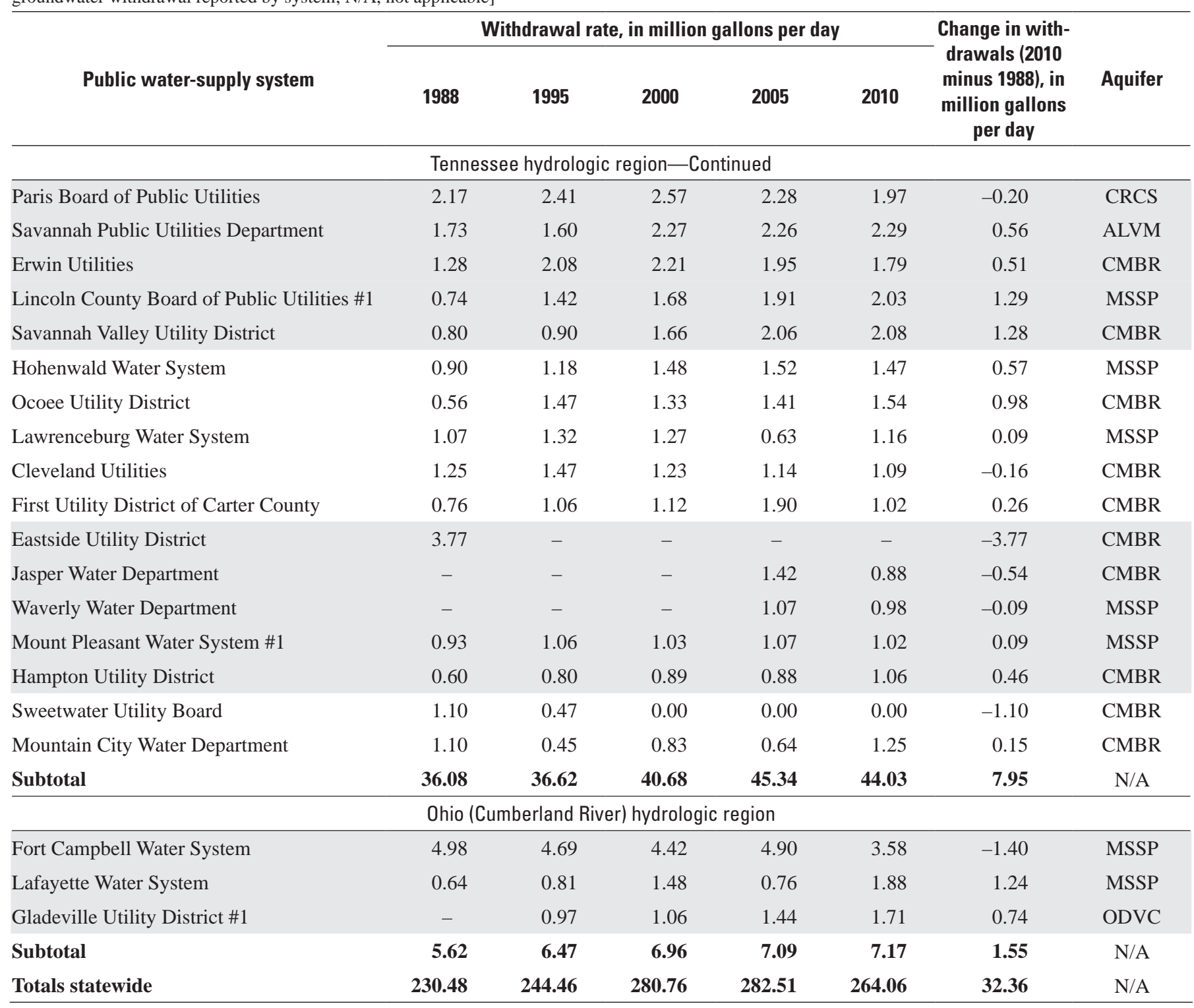




\section{Gross Per Capita Water Use}

Gross per capita water use is the calculated amount of water used in gallons per day (gal/d) and is a means of normalizing or estimating the distribution of water use for county populations within a state or populations across state lines. For this report, the gross per capita for a public-supply water system was calculated from the net supply divided by the number of customers (population) served by the system. The net supply is calculated from the amount of water withdrawn and purchased from specific sources minus the amount of water sold to other public-supply water systems. An average of all gross per capita water-use values was calculated for 2010 and compared to the values of previous years.

Gross per capita water use in Tennessee during 2010 was $162 \mathrm{gal} / \mathrm{d}$. This value is less than reported in 2005 (171 gal/d) by Robinson and Brooks (2010). Per capita values for all public-supply water systems (using surface water, groundwater, and purchased water) that were active in Tennessee during 2010 are listed in appendixes 1, 2, and 3.

\section{Self-Supplied Industrial Water Use During 2010}

Self-supplied industrial water use includes water for such purposes as processing, washing, and cooling in facilities that manufacture various products. Estimates of industrial withdrawals were obtained from the TDEC-DWR. In Tennessee, the primary water-using industries are associated with chemical and allied products (555 Mgal/d), paper and allied products (107 Mgal/d), aeronautical products (71.5 Mgal/d), concrete and glass products (9.74 Mgal/d), and primary metal products (4.49 Mgal/d) (table 5). Together, these industries accounted for 96 percent (747 Mgal/d) of the self-supplied industrial water withdrawals in 2010 (table 5) and other industries accounted for the remaining 4 percent (28.8 Mgal/d) in 2010. Self-supplied industrial water withdrawals in Sullivan County were $488 \mathrm{Mgal} / \mathrm{d}$ and accounted for about 61 percent of the self-supplied industrial water withdrawals (appendix 4).

Water withdrawals for self-supplied industrial water use during 2010 were estimated to be $776 \mathrm{Mgal} / \mathrm{d}$ (fig. 12); this is a decrease of $7 \mathrm{Mgal} / \mathrm{d}$ (1 percent) since 2005 (783 Mgal/d) (Kenny and others, 2009). Surface water supplied 94 percent of the water (728 Mgal/d) for self-supplied industrial purposes, and groundwater supplied 6 percent (47.6 Mgal/d) (fig. 12; appendixes 4, 5, and 6).
Table 5. Self-supplied industrial withdrawals by category and source in Tennessee in 2010.

\begin{tabular}{lccc}
\hline & \multicolumn{3}{c}{ Withdrawal, in million gallons per day } \\
\cline { 2 - 4 } $\begin{array}{c}\text { Industrial } \\
\text { category }\end{array}$ & Groundwater & Surface water & Total \\
\hline $\begin{array}{c}\text { Chemicals and } \\
\text { allied products }\end{array}$ & 21.9 & 533 & 555 \\
\hline $\begin{array}{c}\text { Paper and allied } \\
\text { products }\end{array}$ & 5.09 & 102 & 107 \\
$\begin{array}{c}\text { Aeronautical } \\
\text { products }\end{array}$ & 0.778 & 70.7 & 71.5 \\
\hline $\begin{array}{c}\text { Highway } \\
\text { and heavy } \\
\text { construction }\end{array}$ & 28.1 & 0 & 28.1 \\
$\begin{array}{c}\text { Manufacture of } \\
\text { concrete and } \\
\text { glass }\end{array}$ & 0 & 9.74 & 9.74 \\
\hline $\begin{array}{c}\text { Primary metal } \\
\text { products }\end{array}$ & 1.78 & 2.72 & 4.49 \\
\hline Other & 18.1 & 10.7 & 28.8 \\
\hline
\end{tabular}

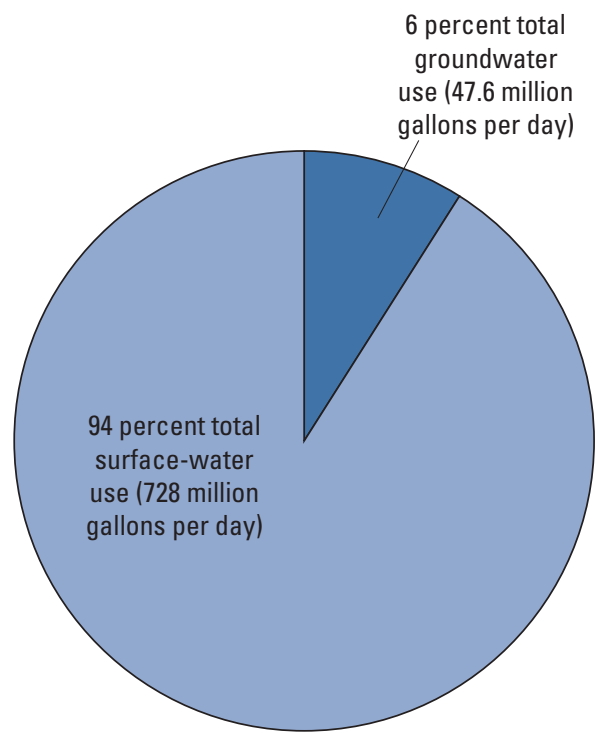

Figure 12. Source of water for self-supplied industry in Tennessee in 2010. 


\section{Surface Water}

All the surface-water withdrawals (table 6 ) by selfsupplied industry in Tennessee happened in counties in the Tennessee and Ohio hydrologic regions; and came from the French Broad-Holston (493 Mgal/d), Middle TennesseeHiwassee (74.0 Mgal/d), Lower Tennessee (70.5 Mgal/d), Middle Tennessee-Elk (59.9 Mgal/d), Upper Cumberland (23.4 Mgal/d), Upper Tennessee (6.19 Mgal/d), and Lower Cumberland (1.50 Mgal/d) River Basins.

Most surface-water withdrawals for self-supplied industry happened in the Tennessee River region. A total of 67 percent of the surface-water withdrawals for self-supplied industry happened in Sullivan County, Tennessee (488 Mgal/d; fig. 13). The largest total withdrawal (459 Mgal/d) by a single self-supplied industry happened in Sullivan County from the South Fork Holston River. This was the largest surface-water withdrawal in the State during 2010. Large amounts of surface water also were withdrawn from the Upper Cumberland River/Old Hickory Lake in Davidson County (the Nashville metropolitan area), Woods Reservoir in Franklin County, the Hiwassee River in McMinn County, the Tennessee River in Humphreys County, and the Tennessee River in Hardin County. Because of the abundance and availability of groundwater supplies (Hutson and Morris, 1992; Hutson, 1999), surface water was not a primary source for selfsupplied industry in the Lower Mississippi hydrologic region of West Tennessee.

\section{Groundwater}

Groundwater supplied 47.6 Mgal/d in 2010 of the total self-supplied industrial water withdrawals in Tennessee (fig. 14), which is an increase of $2.00 \mathrm{Mgal} / \mathrm{d}$ since 2005 (Kenny and others, 2009). A total of 86 percent of the groundwater withdrawn for self-supplied industry during 2010 was reported from West Tennessee. In Shelby County, Tennessee, groundwater withdrawals were $34.3 \mathrm{Mgal} / \mathrm{d}$ (fig. 14) and provided water for chemical and allied products; paper and allied products; and food, fuel, resin, and fiber products. The largest groundwater withdrawal, $14.9 \mathrm{Mgal} / \mathrm{d}$, by a single self-supplied industry was for the production of chemicals and allied products and happened in Memphis, Tennessee. About $40.7 \mathrm{Mgal} / \mathrm{d}$ of groundwater were withdrawn from the Tertiary sand, Cretaceous sand, and alluvial aquifers (figs. 15 and 16). In contrast to the large amount of groundwater used in West Tennessee, the combined withdrawals from aquifers in Middle and East Tennessee were only $6.85 \mathrm{Mgal} / \mathrm{d}$. Short-term, limited use of groundwater withdrawals from wells for highway and heavy construction occurred in Gibson County (7.67 Mgal/d) and Obion County (20.4 Mgal/d) and are not included in the totals but are included in the companion data release (Robinson, 2017).

Table 6. Self-supplied industrial surface-water withdrawals from Tennessee river basins in 2010 .

\begin{tabular}{lc}
\hline \multicolumn{1}{c}{ River basin name } & $\begin{array}{c}\text { Surface-water withdrawal rate, } \\
\text { in million gallons per day }\end{array}$ \\
\hline French Broad-Holston & 493 \\
Middle Tennessee-Hiwassee & 74.0 \\
Lower Tennessee & 70.5 \\
Middle Tennessee-Elk & 59.9 \\
Upper Cumberland & 23.4 \\
Upper Tennessee & 6.19 \\
Lower Cumberland & 1.50 \\
\hline
\end{tabular}




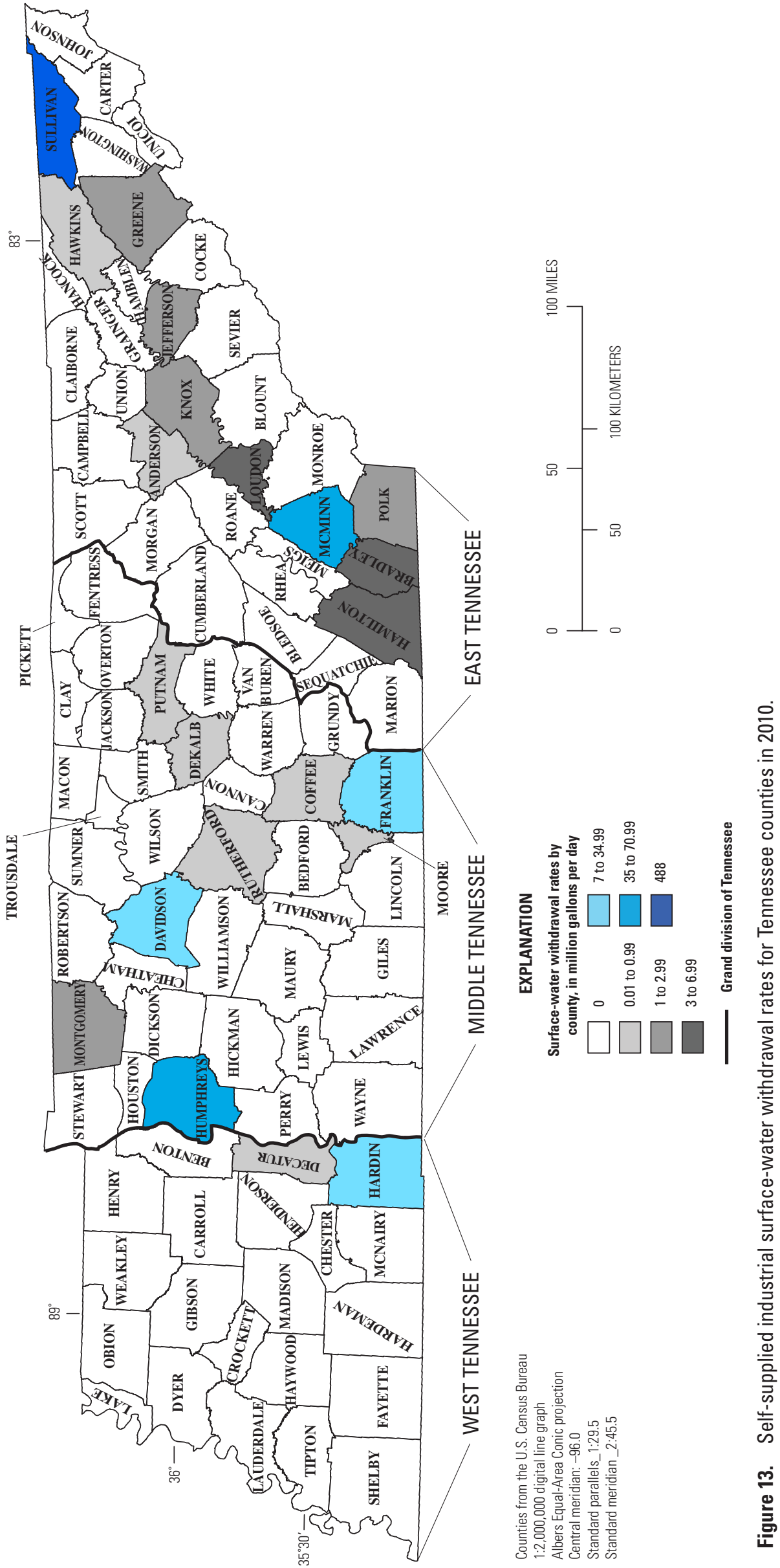




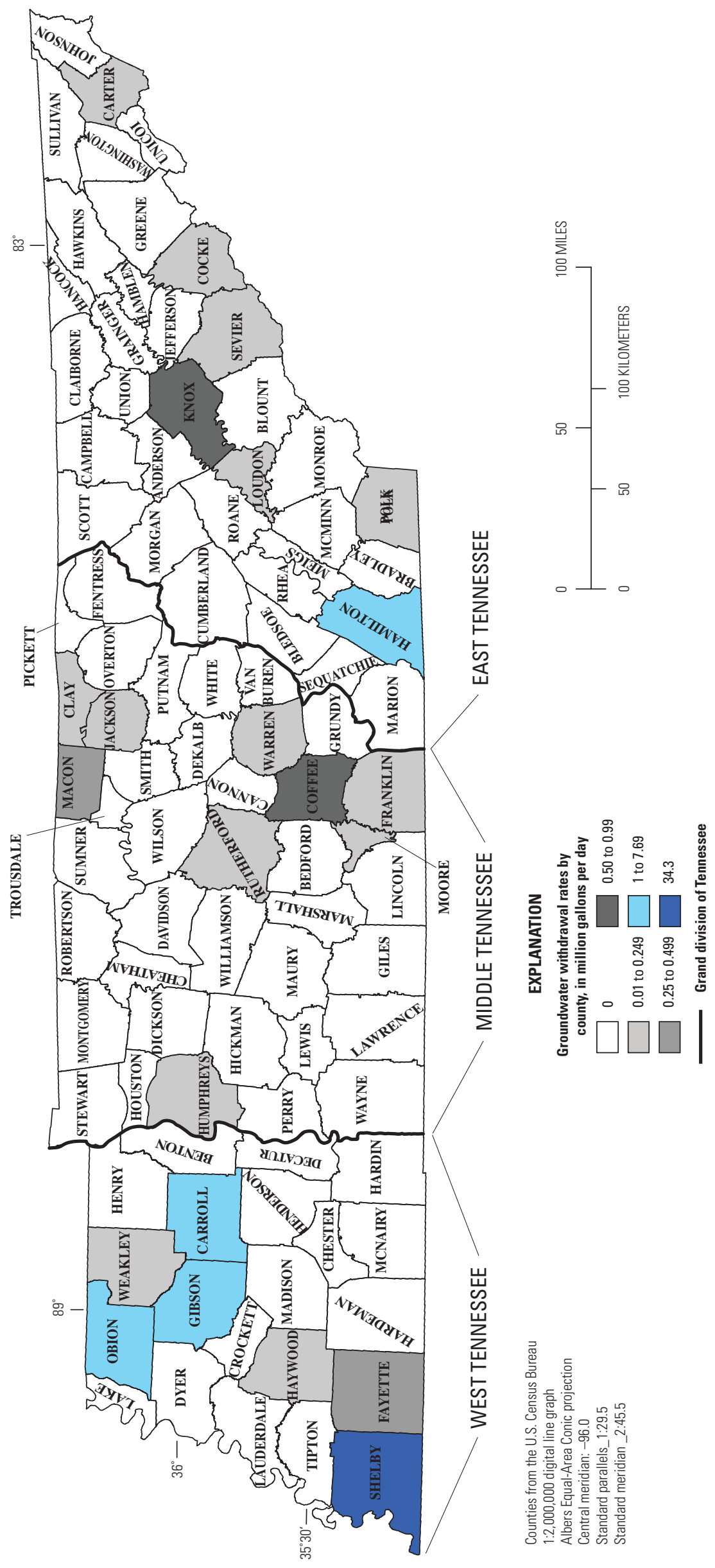

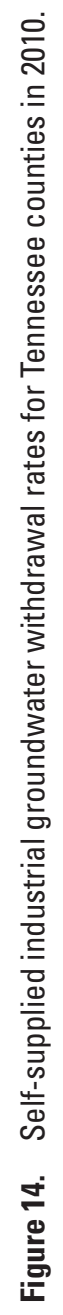




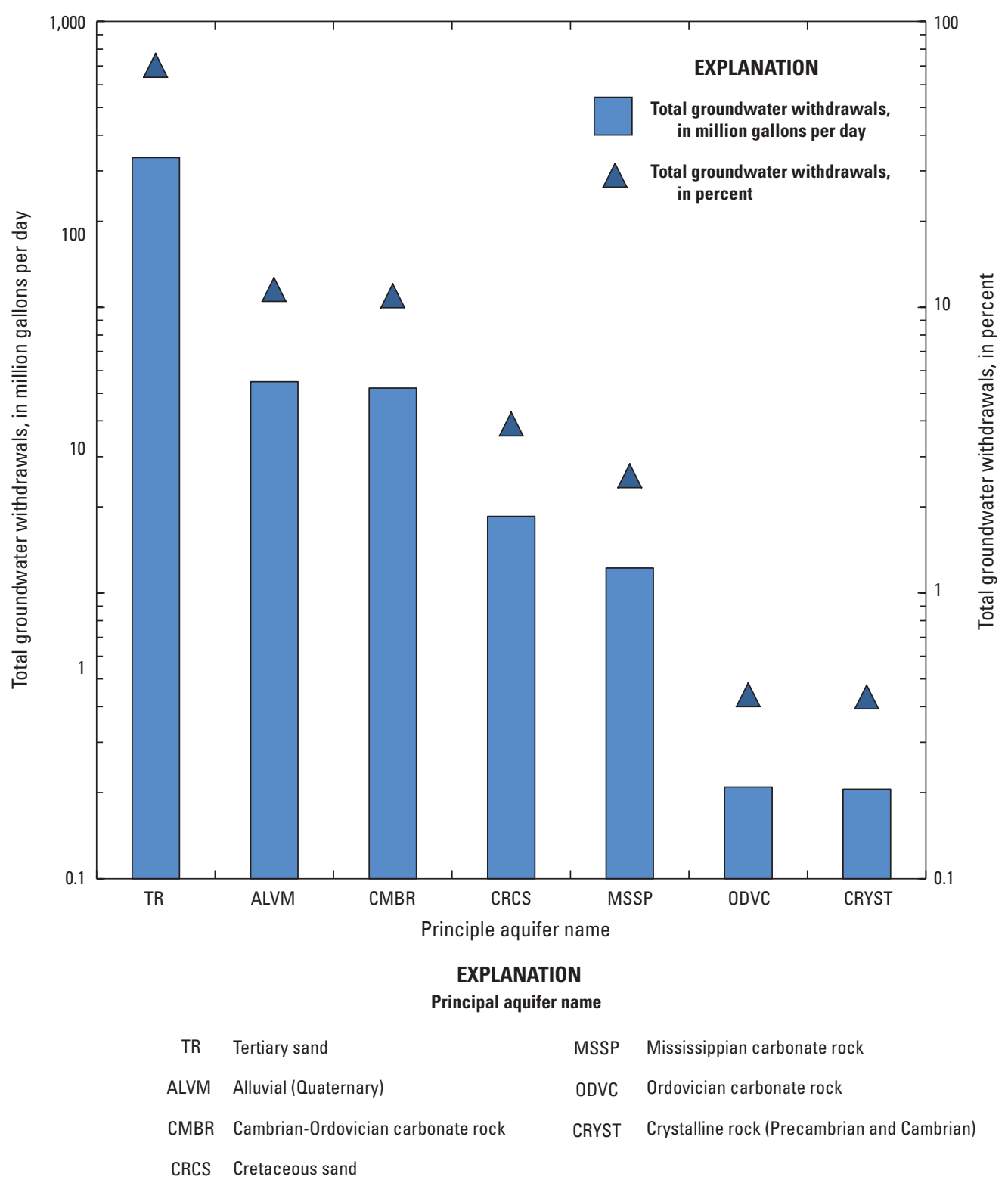

Figure 15. Self-supplied industrial groundwater withdrawals, in million gallons per day and percent, from principal aquifers in Tennessee in 2010. 


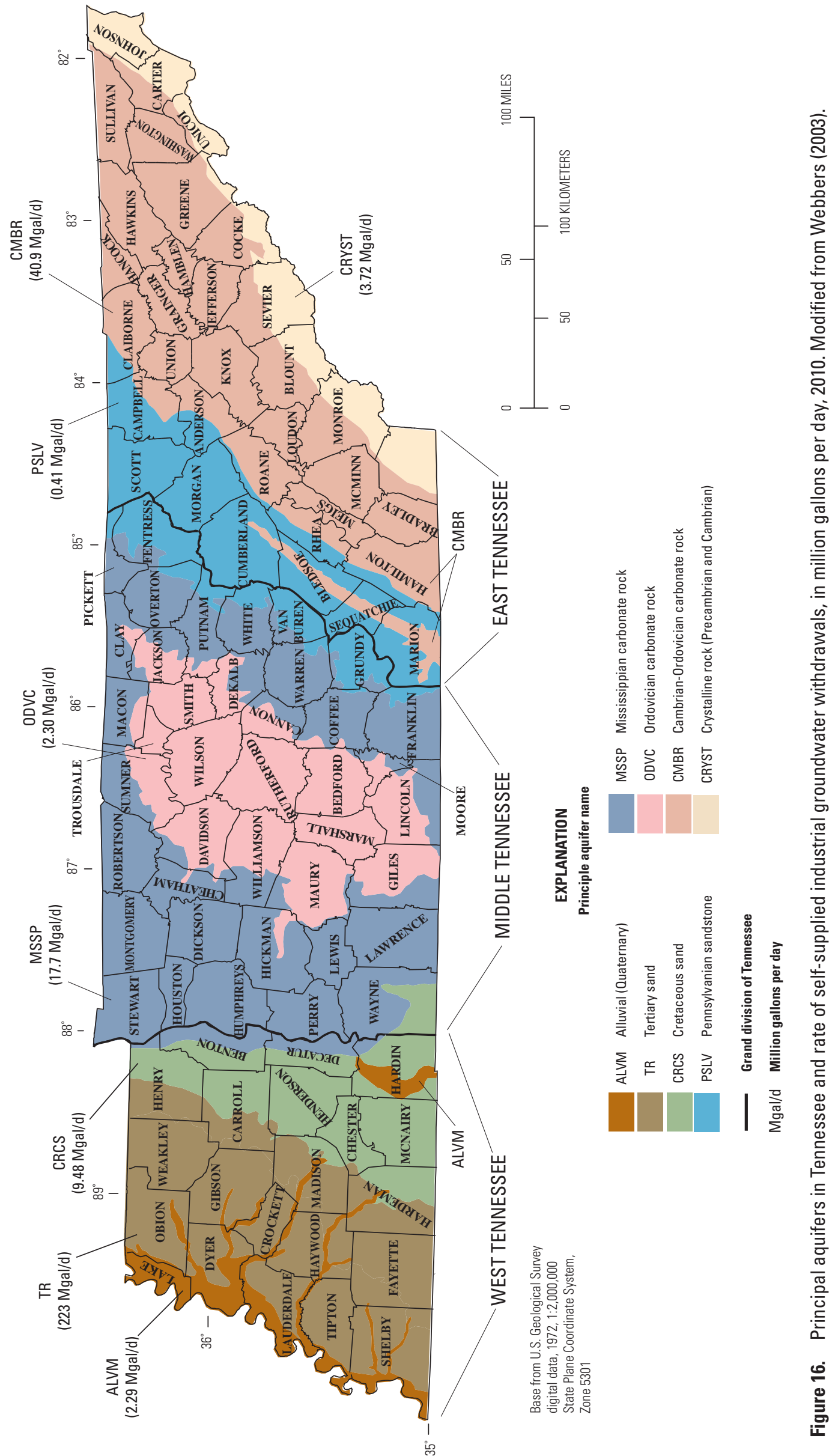




\section{Summary}

The U.S. Geological Survey, in cooperation with the Tennessee Department of Environment and Conservation, Division of Water Resources, performed a detailed analysis of water use by self-supplied industrial and public-supply water systems in Tennessee. Historical data available for publicsupply water use in Tennessee indicate that since 1950 water withdrawals by public-supply water systems in Tennessee have increased from $160 \mathrm{Mgal} / \mathrm{d}$ to $917 \mathrm{Mgal} / \mathrm{d}$ in 2010. During 2010, public-supply water systems of Tennessee withdrew $917 \mathrm{Mgal} / \mathrm{d}$, which is a combined withdrawal of 67 percent surface water (617 Mgal/d) and 33 percent groundwater (300 Mgal/d). Tennessee was served by 474 public-supply water systems that provided surface water and groundwater to a population of 5.7 million. A total of 131 of these systems relied entirely on water purchased from other water systems to provide $74.7 \mathrm{Mgal} / \mathrm{d}$ of purchased water supplies to Tennessee residents. Of the 343 public-supply water systems withdrawing water, 126 systems withdrew surface water and 201 systems withdrew groundwater. Of these 343 systems, 16 used both surface water and groundwater.

The largest groundwater withdrawal rate of $151 \mathrm{Mgal} / \mathrm{d}$ by a single public-supply water system was reported by Memphis Light, Gas and Water in Shelby County in 2010. The county with the largest surface-water withdrawal rate of $136 \mathrm{Mgal} / \mathrm{d}$ was Davidson County. The largest publicsupply withdrawals from surface water by hydrologic region in the State happened in counties in the Tennessee and Ohio hydrologic regions and came primarily from the Lower Cumberland, 244 Mgal/d; Upper Tennessee, 125 Mgal/d; French Broad-Holston, 78.9 Mgal/d; and the Middle Tennessee-Hiwassee, 75.7 Mgal/d River Basins. Surface water supplied $617 \mathrm{Mgal} / \mathrm{d}$ in 2010, which is an increase of $26 \mathrm{Mgal} / \mathrm{d}$ since 2005. About $235 \mathrm{Mgal} / \mathrm{d}$ of groundwater were withdrawn from the Tertiary sand, Cretaceous sand, and alluvial aquifers. In contrast to the large amount of groundwater used in West Tennessee, the combined withdrawals from aquifers in Middle and East Tennessee were $65 \mathrm{Mgal} / \mathrm{d}$. Groundwater supplied $300 \mathrm{Mgal} / \mathrm{d}$ in 2010, which is a decrease of $29 \mathrm{Mgal} / \mathrm{d}$ since 2005. This decrease is the first decrease in groundwater withdrawals since 1950. Gross per capita water use in Tennessee during 2010 was 162 gallons per day.

Self-supplied industrial water use includes water for such purposes as fabrication, processing, washing, diluting, cooling, or production; incorporating water into a product; or for sanitation needs in facilities that manufacture various products. In Tennessee, the primary water-using industries are associated with chemical and allied products, $555 \mathrm{Mgal} / \mathrm{d}$; paper and allied products, $107 \mathrm{Mgal} / \mathrm{d}$; aeronautical products, $71.5 \mathrm{Mgal} / \mathrm{d}$; concrete and glass products, $9.74 \mathrm{Mgal} / \mathrm{d}$; and primary metal products, $4.49 \mathrm{Mgal} / \mathrm{d}$. These industries account for $747 \mathrm{Mgal} / \mathrm{d}$ of the self-supplied industrial water withdrawals in 2010, whereas other industries accounted for $28.8 \mathrm{Mgal} / \mathrm{d}$ in 2010. Self-supplied industrial water withdrawals in Sullivan County were $488 \mathrm{Mgal} / \mathrm{d}$ and accounted for 61 percent of the self-supplied industrial water withdrawals.

Water withdrawals for self-supplied industrial water use during 2010 were estimated to be $776 \mathrm{Mgal} / \mathrm{d}$; this is a decrease of $7 \mathrm{Mgal} / \mathrm{d}$ since 2005 . Surface water supplied 94 percent of the water, $728 \mathrm{Mgal} / \mathrm{d}$, for self-supplied industrial purposes; and groundwater supplied 6 percent, 47.6 Mgal/d.

All the surface-water withdrawals by self-supplied industry in the State happened in counties in the Tennessee and Ohio hydrologic regions and came from the French Broad-Holston, 493 Mgal/d; Middle Tennessee-Hiwassee, 74.0 Mgal/d; Lower Tennessee, 70.5 Mgal/d; Middle Tennessee-Elk, 59.9 Mgal/d; Upper Cumberland, 23.4 Mgal/d; Upper Tennessee, 6.19 Mgal/d; and Lower Cumberland, $1.50 \mathrm{Mgal} / \mathrm{d}$, River Basins.

Most surface-water withdrawals for self-supplied industry happened in the Tennessee River region. A total of 67 percent or $488 \mathrm{Mgal} / \mathrm{d}$ of the surface-water withdrawals for selfsupplied industry happened in Sullivan County, Tennessee. The largest total surface-water withdrawal of $459 \mathrm{Mgal} / \mathrm{d}$ by a single self-supplied industry happened in Sullivan County from the South Fork Holston River. Surface water was not a primary source for self-supplied industry in the Lower Mississippi hydrologic region of West Tennessee because of the abundance and availability of groundwater supplies.

Groundwater supplied 47.6 Mgal/d in 2010 of the total self-supplied industrial water withdrawals in Tennessee, which is an increase of $2.00 \mathrm{Mgal} / \mathrm{d}$ since 2005. A total of 86 percent of the groundwater withdrawn for self-supplied industry during 2010 was reported from West Tennessee. The largest groundwater withdrawal, $14.9 \mathrm{Mgal} / \mathrm{d}$, by a single self-supplied industry was for the production of chemicals and allied products and happened in Memphis, Tennessee. About 40.7 Mgal/d of groundwater were withdrawn from the Tertiary sand, Cretaceous sand, and alluvial aquifers. In contrast to the large amount of groundwater used in West Tennessee, the combined self-supplied industrial withdrawals from aquifers in Middle and East Tennessee were only 6.85 Mgal/d. 


\section{References Cited}

Alexander, F.M., Keck, L.A., Conn, L.G., and Wentz, S.J., 1984, Drought-related impacts on municipal and major selfsupplied industrial water withdrawals in Tennessee-Part B: U.S. Geological Survey Water-Resources Investigations Report 84-4074, 398 p. [Also available at https://pubs.usgs. gov/wri/wri844074B/pdf/wrir_84-4074.pdf.]

Brahana, J.V., and Bradley, M.W., 1985, Delineation and description of regional aquifers of Tennessee-The Knox Aquifer in central and west Tennessee: U.S. Geological Survey Water-Resources Investigations Report 83-4012, 32 p. [Also available at https://pubs.usgs.gov/wri/ wri834012/pdf/wrir_83-4012_a.pdf.]

Brahana, J.V., Macy, J.A., Mulderink, Dolores, and Zemo, Dawn, 1986a, Preliminary delineation and description of the regional aquifers of Tennessee-Cumberland Plateau Aquifer system: U.S. Geological Survey WaterResources Investigations Report 82-338, 24 p. [Also available at https://pubs.usgs.gov/wri/wrir82-338/pdf/ wrir_82-338_a.pdf.]

Brahana, J.V., Mulderink, Dolores, and Bradley, M.W., 1986b, Preliminary delineation and description of the regional aquifers of Tennessee-The Cretaceous Aquifer system of west Tennessee: U.S. Geological Survey WaterResources Investigations Report 83-4039, 20 p. [Also available at https://pubs.usgs.gov/wri/wri834039/pdf/ wrir_83-4039_a.pdf.]

Center for Business and Economic Research, 2012, Tennessee County population projections: The University of Tennessee Knoxville, Excel file, accessed January 2013 at http://cber. bus.utk.edu/data/cntypjoct12.xls.

Fenneman, N.M., 1946, Physical divisions of the United States: U.S. Geological Survey map, scale 1:7,000,000.

Griffin, R.C., 2006, Water resources economics-The analysis of scarcity, policies, and projects: Massachusetts Institute of Technology, $402 \mathrm{p}$.

Hollyday, E.F., and Bradley, M.W., 1985, Tennessee groundwater resources, in National water summary 1984Hydrologic events, selected water-quality trends, and ground-water resources: U.S. Geological Survey WaterSupply Paper 2275, p. 391-396. [Also available at https:// pubs.er.usgs.gov/publication/wsp2275.]

Hutson, S.S., 1989, Ground-water use by public-supply systems in Tennessee in 1985: U.S. Geological Survey Water-Resources Investigations Report 89-4092, 1 sheet. [Also available at https://pubs.er.usgs.gov/publication/ wri894092.]
Hutson, S.S., 1990, Tennessee water supply and use, in National water summary 1987-Hydrologic events and water supply and use: U.S. Geological Survey Water-Supply Paper 2350, p. 467-474. [Also available at https://pubs. er.usgs.gov/publication/wsp2350.]

Hutson, S.S., 1991, Ground-water use by public-supply systems in Tennessee in 1988: U.S. Geological Survey Open-File Report 91-176, 1 sheet. [Also available at https:// pubs.er.usgs.gov/publication/ofr91176.]

Hutson, S.S., 1994, Estimated use of water in Tennessee, 1990: U.S. Geological Survey Water-Resources Investigations Report 94-4055, 1 sheet.

Hutson, S.S., 1999, Public water-supply systems and associated water use in Tennessee, 1995: U.S. Geological Survey Water-Resources Investigations Report 99-4052, $91 \mathrm{p}$.

Hutson, S.S., and Morris, A.J., 1992, Public water-supply systems and water use in Tennessee, 1988: U.S. Geological Survey Water-Resources Investigations Report 91-4195, 74 p. [Also available at https://pubs.usgs.gov/wri/ wri914195/pdf/wrir_91-4195_a.pdf.]

Kenny, J.F., Barber, N.L., Hutson, S.S., Linsey, K.S., Lovelace, J.K., and Maupin, M.A., 2009, Estimated use of water in the United States in 2005: U.S. Geological Survey Circular 1344, 52 p. [Also available at https://pubs.usgs. gov/circ/1344/.]

Kingsbury, J.A., and Parks, W.S., 1993, Hydrogeology of the principal aquifers and relation of faults to interaquifer leakage in the Memphis area, Tennessee: U.S. Geological Survey Water-Resources Investigations Report 93-4075, 18 p. [Also available at https://pubs.er.usgs.gov/publication/ wri934075.]

MacKichan, K.A., 1951, Estimated use of water in the United States-1950: U.S. Geological Survey Circular 115, 13 p. [Also available at https://pubs.usgs.gov/circ/1951/circ115/ htdocs/text.html.]

MacKichan, K.A., 1957, Estimated use of water in the United States, 1955: U.S. Geological Survey Circular 398, 18 p. [Also available at https://pubs.er.usgs.gov/publication/ cir398.]

MacKichan, K.A., and Kammerer, J.C., 1961, Estimated use of water in the United States, 1960: U.S. Geological Survey Circular 456, 44 p. [Also available at https://pubs.er.usgs.gov/ publication/cir456.]

Maupin, M.A., Kenny, J.F., Hutson, S.S., Lovelace, J.K., Barber, N.L., and Linsey, K.S., 2014, Estimated use of water in the United States in 2010: U.S. Geological Survey Circular 1405, 56 p. [Also available at https://doi.org/10.3133/ cir1405.] 
Miller, R.A., 1974, The geology history of Tennessee: State of Tennessee, Division of Geology, Bulletin 74, 63 p.

Murray, C.R., 1968, Estimated use of water in the United States, 1965: U.S. Geological Survey Circular 556, 53 p. [Also available at https://pubs.er.usgs.gov/publication/ cir556.]

Murray, C.R., and Reeves, E.B., 1972, Estimated use of water in the United States in 1970: U.S. Geological Survey Circular 676, 37 p. [Also available at https://pubs.er.usgs. gov/publication/cir676.]

Murray, C.R., and Reeves, E.B., 1977, Estimated use of water in the United States in 1975: U.S. Geological Survey Circular 765, 39 p. [Also available at https://pubs.er.usgs. gov/publication/cir765.]

National Centers for Environmental Information, 2013, 19812010 U.S. climate normal: U.S. Department of Commerce, National Oceanic and Atmospheric Administration, National Centers for Environmental Information, accessed December 2013 at https://www.ncdc.noaa.gov/land-based-station-data/ climate-normals/1981-2010-normals-data.

National Oceanic and Atmospheric Administration, 2011, Extreme weather 2011-Mississippi River floodingSpring-summer, 2011: U.S. Department of Commerce, National Oceanic and Atmospheric Administration, National Climatic Data Center, accessed March 2013 at https://www. noaa.gov/extreme2011/mississippi_flood.html.

National Weather Service, 2010, May 1 \& 22010 epic flood event for western and middle Tennessee: Nashville, Tenn., National Oceanic and Atmospheric Administration, National Weather Service Weather Forecast Office, accessed July 2014 at https://www.srh.noaa.gov/ ohx/?n=may2010epicfloodevent.

Parks, W.S., and Carmichael, J.K., 1989, Geology and ground-water resources of the Fort Pillow Sand in western Tennessee: U.S. Geological Survey Water-Resources Investigations Report 89-4120, 20 p. [Also available at https://pubs.er.usgs.gov/publication/wri894120.]

Robinson, J.A., 2017, Water use in Tennessee, 2010: U.S. Geological Survey data release, https://doi. org/10.5066/F7V9868K.
Robinson, J.A., and Brooks, J.M., 2010, Public watersupply systems and associated water use in Tennessee, 2005: U.S. Geological Survey Open File Report 20101226, 100 p. [Also available at https://pubs.usgs.gov/ of/2010/1226/.]

Solley, W.B., Pierce, R.R., and Perlman, H.W., 1993, Estimated use of water in the United States in 1990: U.S. Geological Survey Circular 1081, 76 p. [Also available at https://pubs.er.usgs.gov/publication/cir1081.]

Tennessee Department of Environment and Conservation, 2015, Water Withdrawal Registration Program: Nashville, Tenn., Tennessee Department of Environment and Conservation, accessed July 2015 at https://www.tn.gov/ environment/article/wr-wq-water-withdrawal-registrationprogram.

U.S. Census Bureau, 2012, Tennessee-2010-Population and housing unit counts-2010 Census of population and housing: Washington, D.C., U.S. Government Printing Office, $\mathrm{CPH}-2-44$, [variously paged]. [Also available at https://www.census.gov/prod/cen2010/cph-2-44.pdf.]

U.S. Drought Monitor, 2007, U.S. Drought Monitor archive: Lincoln, Nebr., The National Drought Mitigation Center, U.S. Drought Monitor, accessed July 2014 at https:// droughtmonitor.unl.edu/MapsAndData/MapArchive.aspx.

U.S. Drought Monitor, 2008, U.S. Drought Monitor archive: Lincoln, Nebr., The National Drought Mitigation Center, U.S. Drought Monitor, accessed July 2014 at https:// droughtmonitor.unl.edu/MapsAndData/MapArchive.aspx.

U.S. Drought Monitor, 2012, U.S. Drought Monitor archive: Lincoln, Nebr., The National Drought Mitigation Center, U.S. Drought Monitor, accessed July 2014 at https:// droughtmonitor.unl.edu/MapsAndData/MapArchive.aspx.

U.S. Geological Survey, 1978, Public water supply, chap. 11.C of National handbook of recommended methods for water data acquisition-Chapter 11-Water use: U.S. Geological Survey, accessed December 17, 2013, at https://pubs.usgs. gov/chapter11/chapter11C.html.

Webbers, A., 2003, Public water-supply systems and associated water use in Tennessee, 2000: U.S. Geological Survey Water-Resources Investigations Report 03-4264, 90 p. [Also available at https://pubs.usgs.gov/wri/ wri034264/PDF/PublicSupply.pdf.] 


\section{Glossary}

Hydrologic region Hydrologic regions are used in the United States to divide and subdivide areas of drainage based on the direction of water flow. Each division is identified by a unique hydrologic unit code (HUC) consisting of two to eight digits. A region (primary geographic area, two digit HUC) contains either the drainage area of a primary river or the combined drainage areas of a series of rivers. A subregion (four digit HUC) includes the area drained by a river system, a reach of a river and its tributaries in that reach, a closed basin(s), or a group of streams forming a coastal drainage area. Hydrologic Accounting unit (six digit HUC) boundaries are used by the U.S. Geological Survey for designing and managing the National Water Data Network.

Industrial water use Water used for industrial purposes such as fabrication, processing, washing, and cooling and includes such industries as steel, chemical, and allied products; paper and allied products; mining products; and petroleum refining products. The water may be obtained from a public supply or may be self-supplied. See also public-supply water use and self-supplied water.

Public-supply water use Public-supply water use refers to water use by public and private utilities for delivery to domestic, commercial, and industrial users; and for municipal services such as firefighting. Water lost by leaky pipes in the distribution system (conveyance losses) and system maintenance is included in this category.

Self-supplied water Water withdrawn from a surface water or groundwater source by a user rather than being obtained from public supply.

Water use In this report, the quantity of water use for a specific category is the combination of water-supply withdrawals and public-supply deliveries. In a restrictive sense, the term refers to water that is actually used for a specific purpose such as for domestic use, irrigation, or industrial processing. More broadly, water use pertains to human interaction with the hydrologic cycle and includes dimensions such as water withdrawal, delivery, consumptive use, wastewater release, reclaimed wastewater, return flow, and instream use.

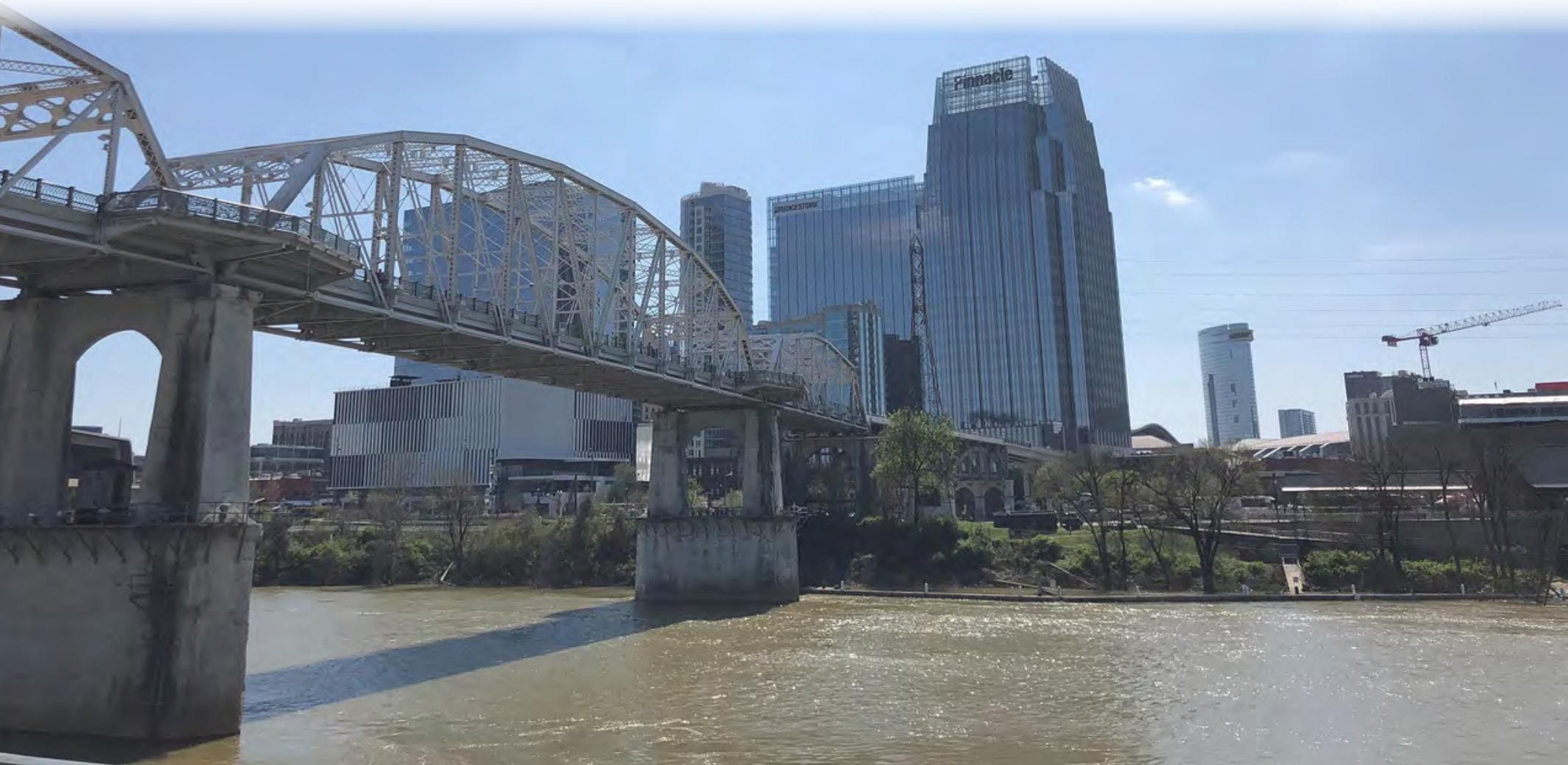


Appendix 1. Public-Supply Water Systems and Associated Water Use in the Tennessee Hydrologic Region, 2010.

The data in appendix 1 are available in a U.S. Geological Survey data release (Robinson, 2017) and for download at https://doi.org/10.3133/sir20185009.

\section{Appendix 2. Public-Supply Water Systems and Associated Water Use in the Ohio Hydrologic Region, 2010.}

The data in appendix 2 are available in a U.S. Geological Survey data release (Robinson, 2017) and for download at https://doi.org/10.3133/sir20185009.

\section{Appendix 3. Public-Supply Water Systems and Associated Water Use in the Lower-Mississippi Hydrologic Region, 2010.}

The data in appendix 3 are available in a U.S. Geological Survey data release (Robinson, 2017) and for download at https://doi.org/10.3133/sir20185009.

\section{Appendix 4. Self-Supplied Industrial Water Use in the Tennessee Hydrologic Region, 2010.}

The data in appendix 4 are available in a U.S. Geological Survey data release (Robinson, 2017) and for download at https://doi.org/10.3133/sir20185009.

\section{Appendix 5. Self-Supplied Industrial Water Use in the Ohio Hydrologic Region, 2010.}

The data in appendix 5 are available in a U.S. Geological Survey data release (Robinson, 2017) and for download at https://doi.org/10.3133/sir20185009.

\section{Appendix 6. Self-Supplied Industrial Water Use in the Lower Mississippi Hydrologic Region, 2010.}

The data in appendix 6 are available in a U.S. Geological Survey data release (Robinson, 2017) and for download at https://doi.org/10.3133/sir20185009.

\section{Appendix 7. Public-Supply Water Systems in Tennessee, 2010.}

The data in appendix 7 are available in a U.S. Geological Survey data release (Robinson, 2017) and for download at https://doi.org/10.3133/sir20185009. 


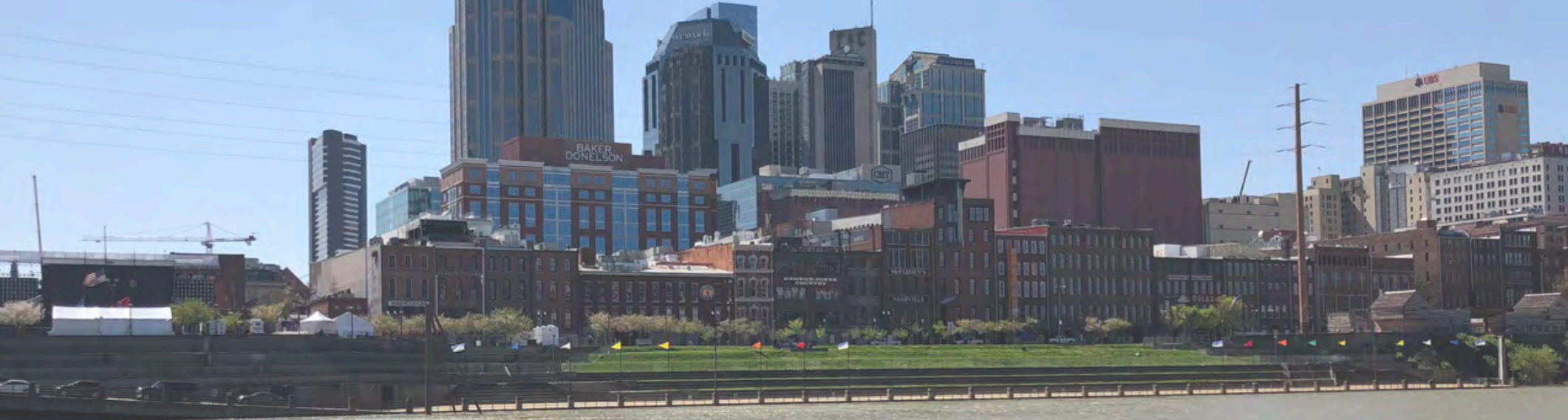





\section{这}

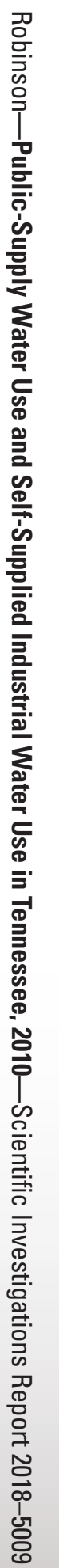

